\title{
GUIDELINES FOR THE DIAGNOSIS AND MANAGEMENT OF GASTROESOPHAGEAL REFLUX DISEASE: an evidence-based consensus
}

\author{
Joaquim Prado P. MORAES-FILH0 ${ }^{1}$, Tomas NAVARRO-RODRIGUEZ1', Ricardo BARBUTI', \\ Jaime EISIG' ${ }^{1}$, Decio CHINZON ${ }^{1}$, Wanderley BERNARDO ${ }^{2}$ and the Brazilian GERD Consensus Group*2
}

\begin{abstract}
Gastroesophageal reflux disease (GERD) is one of the most common disorders in medical practice. A number of guidelines and recommendations for the diagnosis and management of GERD have been published in different countries, but a Brazilian accepted directive by the standards of evidence-based medicine is still lacking. As such, the aim of the Brazilian GERD Consensus Group was to develop guidelines for the diagnosis and management of GERD, strictly using evidence-based medicine methodology that could be clinically used by primary care physicians and specialists and would encompass the needs of physicians, investigators, insurance and regulatory bodies. A total of 30 questions were proposed. Systematic literature reviews, which defined inclusion and/or exclusion criteria, were conducted to identify and grade the available evidence to support each statement. A total of 11,069 papers on GERD were selected, of which 6,474 addressed the diagnosis and 4,595, therapeutics. Regarding diagnosis, 51 met the requirements for the analysis of evidence-based medicine: 19 of them were classified as grade A and 32 as grade B. As for therapeutics, 158 met the evidence-based medicine criteria; 89 were classified as grade A and 69 as grade B. In the topic Diagnosis, answers supported by publications grade A and B were accepted. In the topic Treatment only publications grade A were accepted: answers supported by publications grade B were submitted to the voting by the Consensus Group. The present publication presents the most representative studies that responded to the proposed questions, followed by pertinent comments. Follow examples. In patients with atypical manifestations, the conventional esophageal $\mathrm{pH}$-metry contributes little to the diagnosis of GERD. The sensitivity, however, increases with the use of double-channel $\mathrm{pH}$-metry. In patients with atypical manifestations, the impedance-pHmetry substantially contributes to the diagnosis of GERD. The examination, however, is costly and scarcely available in our country. The evaluation of the histological signs of esophagitis increases the diagnostic probability of GERD; hence, the observation of the dimensions of the intercellular space of the esophageal mucosa increases the probability of diagnostic certainty and also allows the analysis of the therapeutic response. There is no difference in the clinical response to the treatment with PPI in two separate daily doses when compared to a single daily dose. In the long term (>1 year), the eradication of $H$. pylori in patients with GERD does not decrease the presence of symptoms or the high recurrence rates of the disease, although it decreases the histological signs of gastric inflammation. It seems very likely that there is no association between the eradication of the $H$. pylori and the manifestations of GERD. The presence of a hiatal hernia requires larger doses of proton-pump inhibitor for the clinical treatment. The presence of permanent migration from the esophagogastric junction and the hernia dimensions $(>2 \mathrm{~cm})$ are factors of worse prognosis in GERD. In this case, hiatal hernias associated to GERD, especially the fixed ones and larger than $2 \mathrm{~cm}$, must be considered for surgical treatment. The outcomes of the laparoscopic fundoplication are adequate.
\end{abstract}

HEADINGS - Gastroesophageal reflux. Esophagitis, peptic. Guidelines as topic.

\section{INTRODUCTION}

Gastroesophageal reflux disease (GERD) is one of the most common disorders in medical practice. Data from North America ${ }^{(74)}$ indicate that heartburn, the most predominant symptom of the disorder, occurs at least once a week in $20 \%$ of the studied population. Similar data have been reported in England and Scotland ${ }^{(56)}$. In Brazil, a population-based national study showed a prevalence of at least $12 \%$ in the general population ${ }^{(93)}$.

\footnotetext{
* Brazilian GERD Consensus Group: Aloisio Carvalhaes, Angelo P. Ferrari, Antonio Frederico N. Magalhaes, Ary Nasi, Celso M. Paula e Silva, Claudio Hashimoto, Decio Chinzon, Edson P. Silva, Eduardo Moura, Eponina Lemme, Farid Nader, Fauze Maluf Filho, Gerson Domingues, Igelmar Barreto, Isac Jorge Filho, Ismael Maguilnik, Ivan Cecconello, Jaime Eisig, Joaquim P. Moraes-Filho, Joffre Rezende Filho, José Luis P. Modena, Jose Roberto de Almeida, Lilian Aprile, Luciana Camacho-Lobato, Luciana Moretzohn, Marcelo Cury, Marcio Tolentino, Marco Aurelio Santo, Marcos Kleiner, Marcus T. Haddad, Maria do Carmo Passos, Olavo G. Mion, Oswaldo Malafaia, Paulo S Rocha, Rafael Stelmach, Ricardo A. Correa, Ricardo Barbuti, Richard Gursky, Rimon S. Azzam, Roberto El Ibrahim, Roberto Dantas, Rubens Sallum, Schlioma Zaterka, Sergio Barros, Tomas Navarro-Rodriguez, Ulysses Meneghelli, Wilson Pollara.

'Working Group: Department of Gastroenterology, University of São Paulo School of Medicine; ${ }^{2 B}$ razilian Medical Association, São Paulo, SP, Brazil.

Correspondence: Prof. Joaquim Prado P. Moraes Filho - Rua Itapaiuna, 1165 - casa 28 - 05707-001 - São Paulo, SP.
} 
A number of guidelines and recommendations for the diagnosis and management of GERD have been published in different countries ${ }^{(18,29,35,56,74,92,93,138)}$, but an updated South American, particularly Brazilian, accepted directive by the standards of evidence-based medicine is still lacking. As such, the aim of the Brazilian GERD Consensus Group was to develop guidelines for the diagnosis and management of GERD strictly using methodology that could be clinically used by primary care physicians and specialists and would encompass the needs of physicians, investigators, insurance and regulatory bodies. Furthermore, it should be representative of the Brazilian medical community and relevant.

\section{METHODS}

The main steps in the process of these guidelines were: 1) selection of the Consensus Group; 2) development of draft statements by the Working Group; 3 ) systematic literature reviews to identify the evidence to support each statement; 4) grading of the evidence; 5) diagnosis: grade A or B recommendations were accepted by the Consensus Group; treatment: voting discussion was conducted on the statements when the grade A was not achieved.

Members of the GERD Consensus Group were selected based upon the following criteria: demonstrated expertise/ knowledge in GERD by publication/research and/or participation in national or international consensus guidelines and diversity of views and expertise.

A specialist (WB) in medicine-based evidence from the Brazilian Medical Association, the national official medical society, was responsible for the systematic literature reviews. The Working Group developed the initial statements and reviewed the evidence to support the statements that were presented to the Consensus Group which consisted of 47 experts (10 GI surgeons, seven endoscopists, one pathologist, one pneumologist, one ear-nose and throat specialist and 27 gastroenterologists). Systematic literature reviews, which defined inclusion and/or exclusion criteria, were conducted to identify and grade the available evidence to support each statement. The literature search was conducted in English, French, German, Spanish and Portuguese publications in the Medline, Embase and Scielo-Lilacs databases and in the Cochrane Trials Register in human subjects from May 1966 onwards. A number of search strings were used that are too numerous to be listed in this publication, but its complete list can be obtained by communicating with the author (WB) of the present article. The review was initially qualitative when the primary reviewer reached an assessment on the grade assigned to the statement. After that, the material was reviewed by the Working Group. Quantitative meta-analyses were not performed. The references cited in this paper constitute only a fraction of all the articles reviewed in each area and were selected to confirm the statements.

The following concepts were used in this text: 1) GERD - is a condition which develops when the reflux of stomach contents causes troubling symptoms and/or complications $^{(138)}$; 2) likelihood ratio (LR) - indicates the degree of certainty and the possibility of error and expresses how many times the positivity of a certain diagnostic test result is more or less likely to occur in individuals with the disease when compared to disease-free individuals. A LR of 1 indicates that the post-test probability is the same as the pre-test one, that is, of the prevalence of the disease in the general population; 3 ) sensibility (SB) is the proportion of individuals who present a positive test result for a certain disease that effectively has the disease (true-positives); 4) specificity (SP) is the proportion of individuals without the disease that present a negative-result test for the same disease (true-negatives) ${ }^{(7)}$.

The assignment of the grade of evidence and levels of recommendation were established according to the classification of the Oxford Centre for Evidence-Based Medicine for levels of evidence (EBM) ${ }^{(103)}$. Grade A is highly recommended and corresponds to level-1 studies, which means systematic review of randomized controlled trials or a large randomized trial with low probability of bias or without bias. Grade B is recommended and corresponds to level-2 studies, in other words, systematic review of cohort studies, with homogeneity, individual cohort studies, noncontrolled cohort studies/ecological studies and systematic review of case-control studies with homogeneity. Grades C and D correspond to non-controlled studies, case reports and reports based on consensus, physiological and animalmodel studies.

The grade assessment was performed by the Working Group together with the Brazilian Medical Association representative. In the diagnosis set, grade A and B recommendations resulted in unanimous acceptance by the consensus group. In the management part of the work, only grade A recommendations were accepted by unanimous acceptance; grade B recommendations were accepted by consensus upon voting by the Consensus Group.

The level of agreement in the final vote was given to each statement, expressed as percentages.

The process was funded by unrestricted grants from AstraZeneca, Janssen-Cilag, Medley and Nycomed laboratories. The promoters were: Department of Gastroenterology of the University of São Paulo School of Medicine, Group of Studies of Esophageal Diseases of the University of São Paulo-GREDES, Brazilian Federation of Gastroenterology, Brazilian Society of Digestive Motility, Brazilian Society of Digestive Endoscopy and Brazilian College of Digestive Surgery.

\section{RESULTS AND COMMENTS}

A total of 29 statements were proposed. A total of 11,069 papers were selected, of which 6,474 on the diagnosis of GERD and 4,595 on therapeutics. About diagnosis, 51 fulfilled the requirements for the analysis of EBM: 19 of them were classified as grade A and 32 as grade B. On therapeutics, 158 fulfilled the EBM criteria and 89 were classified as grade A and 69 as grade B. For the purpose of this publication, only the more relevant papers are quoted in each question. 


\section{DIAGNOSIS}

The diagnosis of typical GERD begins with a detailed clinical history. The typical symptoms of GERD are heartburn and regurgitation. The history should identify the characteristic symptom and define their intensity, duration and frequency; uncover the triggering and relieving factors and determine the pattern of evolution of the disorder over time, as well as its impact on the quality of the patients' life. In this context, it is important to consider their age and the presence or absence of alarm manifestations, which include dysphagia, odynophagia, weight loss, GI bleeding, nausea and/or vomiting and a family history of cancer. On the other hand, the absence of typical symptoms does not exclude the diagnosis of GERD. Numerous other manifestations related to gastroesophageal reflux and considered atypical have been described, such as retrosternal chest pain without evidence of coronary artery disease, asthma, chronic cough, hoarseness, etc. ${ }^{(92)}$.

\section{1) Should adult patients presenting GERD manifestations (heartburn and/or regurgitation) without alarm manifestations (weight loss, GI bleeding, nausea and/vomiting, dysphagia, odynophagia, family history of cancer (ref JP) be submitted to an upper digestive endoscopy (UDE) before the treatment? \\ Grade $A$ recommendation}

In patients with a mean age of 54 years, the presence of heartburn and retrosternal burning pain has a SB of $67 \%$, SP of $77 \%$ and a positive LR of 2.83 in the diagnosis of GERD. The absence of the symptom pyrosis has a SB of $33 \%$, SP of $24 \%$ and a negative LR of 0.44 to rule out the diagnosis of GERD ${ }^{(63)}$. In patients with a mean age of 42 years and GERD symptoms, the use of seven-symptom scales, when compared to the UDE, results in a SB, SP and, positive $L R$ and negative $\mathrm{LR}$ of $74.3 \%, 71.6 \%, 2.61$ and 0.36 , respectively ${ }^{(134)}$. In patients with GERD, the symptomatic response after 4 weeks of empiric treatment with $40 \mathrm{mg} /$ day of esomeprazole $(86.4 \%)$ is equivalent to the treatment preceded by UDE (87.5\%). Similarly, after the maintenance treatment for 24 weeks with esomeprazole ( $20 \mathrm{mg} /$ day), a similar proportion of patients remained responsive: $71.8 \%$ vs $68.3 \%$, respectively ${ }^{(39)}$.

Comment. The signs and symptoms are insufficient to establish a conclusive diagnosis of GERD, regardless of their frequency and intensity, resulting in a diagnostic certainty of around $40 \%$. Endoscopy is not usually performed in young adults patients with typical history of GERD since it does not alter the clinical evolution when compared to the empiric treatment.

\section{2) Should patients with typical symptoms occurring at a frequency higher than twice a week, for a period not shorter than 4 weeks and that present normal UDE results be diagnosed with GERD? \\ Grade A recommendation \\ In patients with typical GERD symptoms and a mean age of 47 years and a negative UDE result, the score of symptoms}

classified as moderate and severe does not identify patients with GERD (SB: $82 \%$; SP: 22\%; positive LR: 1.05 and negative LR:0.81). The 7-day proton-pump inhibitor (PPI) test with $60 \mathrm{mg} /$ day of lansoprazole results in a SB of $97 \%$, SP of $6 \%$ positive LR of 1.03 and negative LR of $0.03^{(121,124)}$.

Comment. In patients with non-erosive GERD, the use of the symptom score (moderate or severe) allows a diagnostic certainty of up to $40 \%$ of the cases. In these cases, the UDE does not alter the clinical evolution, when compared to the empiric treatment. It is interesting to remember that, in cases of erosive GERD with typical symptoms, however, the UDE improves the diagnostic accuracy and also establishes a differential diagnosis with other diseases, such as cancer.

\section{3) Should patients with heartburn (pyrosis) and UDE result that does not show the presence of esophageal lesions be submitted to 24-hour esophageal pH-metry for diagnostic confirmation? Grade A recommendation}

In patients with typical GERD symptoms and UDE that does not show the presence of esophageal lesions with typical reflux symptoms, the esophageal $\mathrm{pH}$-metry, using a cutoff of 4.5 of the total time, with a $\mathrm{pH}<4$ during the entire 24-hour period, has a SP of $90.4 \%$ and a SB of $93.3 \%$, with a positive LR of 9.7 in the diagnosis of GERD and a negative LR of 0.07 to rule out the diagnosis ${ }^{(143)}$.

Comment. The 24-hour $\mathrm{pH}$-metry is an important resource for a definite diagnosis of acid reflux, which constitutes most of reflux episodes, establishing or ruling out the diagnosis with a $90 \%$ and $95 \%$ certainty, respectively. The availability of the method in Brazil, however, is still somehow limited and its cost is relatively high.

\section{4) Is the wireless esophageal pH capsule and

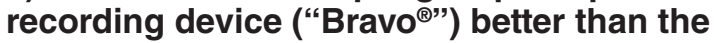 prolonged conventional $\mathrm{pH}$-metry for the diagnosis of GERD?}

\section{Grade $B$ recommendation}

The patients reported discomfort with both methods: "Bravo" $=73 \%$, conventional method $=97 \%$, although the first was less uncomfortable than the last. The patients monitored by the wireless capsule and recording device for esophageal $\mathrm{pH}$ reported less interference with the daily activities, during sleep and at work (14\%) than those studied by conventional $\mathrm{pH}$-metry $(82 \%)^{(41)}$. The adverse effects were on average lower in patients that underwent the assessment with the wireless capsule than those submitted to the conventional $\mathrm{pH}$-metry, as well as in their physical, work and daily activities. The rates of examinations considered normal were similar: wireless capsule and recording device for esophageal $\mathrm{pH}(68 \%)$ and prolonged conventional $\mathrm{pH}$-metry $(71 \%)$. During the first 24 hours the number of recorded events was significantly higher in patients submitted to the conventional $\mathrm{pH}$-metry $(\mathrm{n}=40)$ than in those with the wireless capsule $(\mathrm{n}=23)^{(144)}$.

Comments. During the analyzed study time (24 hours), the methods are equivalent, although the use of the wireless capsule for esophageal $\mathrm{pH}$ recording presents, in comparison with 
the conventional $\mathrm{pH}$-metry, less discomfort, less interference with the daily activities of work and sleep. Studies on the eventual advantages of the use of the wireless capsule for longer periods are scarce and are necessary. In our country the use of the wireless capsule is scarcely available.

\section{5) Should all patients with atypical manifestations (non-cardiac chest pain, globus, asthma, chronic cough, bronchitis, bronchiectasis, recurrent pneumonia, hoarseness, "throat clearing", laryngitis, sinusitis, otalgia, etching of dental enamel, halitosis) undergo a 24-hour esophageal pH-metry? \\ Grade $B$ recommendation}

The majority $(69.4 \%)$ of the atypical episodes occurs regardless of the reflux. In 15\% of the cases, the coughing is preceded by reflux ${ }^{(125)}$. The SB and SP of the conventional esophageal $\mathrm{pH}$-metry in patients with chest pain of non-cardiac origin that do not present heartburn and/or regurgitation is $33 \%$ and $24 \%$, respectively and, therefore, has low diagnostic value in GERD ${ }^{(100)}$. In patients with chronic cough and altered esophageal $\mathrm{pH}$-metry $(56.2 \%)$, the treatment with omeprazole $(40 \mathrm{mg} / \mathrm{day}-8$ weeks) resulted in a partial response rate of $40.8 \%$ and a non-response rate of $55.1 \%$. Among patients with the same diagnosis that did not undergo treatment, $54.5 \%$ had complete resolution of the coughing at the long-term follow-up (30 months). There was no significant difference between those that underwent and the ones that did not undergo treatment with $\mathrm{PPI}^{(143)}$. At the investigation of patients with GERD symptoms (diagnosed by impedance-pH-metry), the acid reflux is more associated to patients with typical symptoms and the non-acid reflux to those with atypical symptoms ${ }^{(143)}$.

Comments. In patients with atypical manifestations, the conventional esophageal $\mathrm{pH}$-metry contributes little to the diagnosis of GERD. The current available evidence does not support the routine use of proximal $\mathrm{pH}$ monitoring.

\section{6) In patients with atypical GERD manifestations, what is the contribution of esophageal impedance/ pH-metry?}

Grade A recommendation

In the detection of acid reflux, the 24-hour pH-metry, compared with the impedance/pH-metry association (gold standard) has $68 \%$ of SP (criterion: $\mathrm{pH}<4$ ) and $67 \%$ when the criterion is the index of symptoms. The percentage at which the $\mathrm{pH}$ was $<4$ was significantly higher in $\mathrm{pH}$-metry than in the impedance/pH-metry association. In the detection of weakly acid reflux, the pH-metry has a SB of $28 \%$ when compared to the association of methods, with an $83 \%$ rate of false-positive results ${ }^{(49)}$.

\section{Grade $B$ recommendation}

The non-acid or weakly acid reflux is more associated with the atypical GERD manifestations ${ }^{(49)}$. The prevalence of GERD (diagnosed by UDE, prolonged $\mathrm{pH}$-metry and impedancemetry) in patients with atypical symptoms is of $63.4 \%$ and the diagnosis is established by $\mathrm{pH}$-metry in $46.3 \%$, by impedancemetry in $48.8 \%$ and by the association of the two methods in $61.0 \% 0^{(5)}$.

Comments. In patients with atypical manifestations, the impedance-pH-metry substantially contributes to the diagnosis of GERD. However the examination is costly and scarcely available in our country.

\section{7) In a significant number of patients with GERD, the disease remains resistant to the conventional treatment of acid suppression with PPI (standard dose, administered in the morning in the fasting state, for a period of 4 to 8 weeks), being then called refractory ${ }^{(2)}$. Is the esophageal biopsy a recommended procedure in patients with refractory GERD?}

\section{Grade A recommendation}

In patients with GERD, the pre-treatment thickness of the lamina propria is associated with the degree of esophagitis severity. After treatment with esomeprazole (standard dose), the basal lamina thickness significantly decreases in patients with non-erosive and erosive GERD (particularly in those classified as C and D in the endoscopic classification of Los Angeles) ${ }^{(139)}$

\section{Grade $B$ recommendation}

The use of the score of histological alterations (basal lamina hyperplasia, intercellular space dilation, eosinophilia, neutrophilia, erosion/necrosis, papillary stretching), employing a cutoff $>2$, differentiated individuals with non-erosive GERD from the healthy ones, with a SB and SP of $76 \%$ and $85 \%$, respectively (positive $\mathrm{LR}=5$ and negative $\mathrm{LR}=0.28$ ). It also differentiated individuals with erosive GERD from the healthy ones with a SB and SP of $84 \%$ e $85 \%$, respectively (positive LR $=5.6$ and negative LR of 0.18 ). The biopsies were performed in the squamous-columnar junction, one $2 \mathrm{~cm}$ and one $4 \mathrm{~cm}$ above the squamous-columnar junction ${ }^{(149)}$. The 1-year follow-up of patients with erosive GERD undergoing treatment with PPI (lansoprazole, $30 \mathrm{mg} /$ day, for 8 weeks, followed by lansoprazole 15 to $30 \mathrm{mg}$ /day or omeprazole 20 $\mathrm{mg}$ /day) shows, through the histopathological analysis of the esophageal biopsy fragment, that there was a decrease in the high-degree hyperplasia of the basal lamina, from $51 \%$ to $2 \%$ and an increase in the normal epithelium from $8 \%$ to $63 \%{ }^{(129)}$. In patients with GERD submitted to UDE and esophageal biopsy during the follow-up of the treatment with PPI for 90 days, presenting incomplete epithelial recovery with the presence of sporadic symptoms, the treatment with PPI can be extended, increasing the response, also correlated with the recovery of the intercellular space dilation ${ }^{(10)}$.

Comments. In patients undergoing prolonged treatment with PPI, the histological esophageal alterations can remain practically unaltered, regardless of the occurrence or not of symptoms and signs. On the other hand, the histological alterations accompany the degree of severity of the esophagitis. Therefore, the evaluation of the histological signs increases the diagnostic probability of GERD. The observation of the dimensions of the distal esophagus intercellular space 
increases the probability of diagnostic certainty and also allows the analysis of the therapeutic response. The intercellular space dilation can, preferentially, be observed by electronic microscopy, although the diagnosis in this case is costly and not easily available (See question 8).

\section{8) What is the importance of the intercellular space dilation in the diagnosis of GERD? Grade $A$ recommendation}

In the combined assessment comprising the histological alterations for the GERD diagnosis, the intercellular space dilation as an isolated alteration has a SB and a SP of $86 \%$ and $70 \%$, respectively with a positive LR of 2.86 and a negative LR of $0.23^{(149)}$.

\section{Grade $B$ recommendation}

In patients with GERD symptoms submitted to the esophageal ph-metry assessment, the presence of intercellular space dilation is able to identify patients with the non-erosive and erosive forms of the disease, with a SB of $68.2 \%$ and $90.1 \%$, respectively and SP of $91.7 \%$. The positive LR increases the diagnostic probability in, respectively, $8.2 \%$ and $10.8 \%$ and the negative LR show a 3 and 10 -fold increase, respectively ${ }^{(126)}$. The dimensions of the intercellular space in patients with erosive and non-erosive GERD are three and two-fold larger in the distal and proximal esophagus, respectively, than in healthy individuals. These variations in intercellular space dimensions accompany the time of acid exposure obtained through the $\mathrm{pH}$-metry ${ }^{(17)}$. The dimensions of the intercellular space are, on average, 4-fold larger in patients with erosive and non-erosive GERD than in patients without reflux ${ }^{(11)}$. After three months of treatment with omeprazole ( $40 \mathrm{mg} /$ day) $92 \%$ of the patients presented recovery of the intercellular space as well as symptom resolution ${ }^{(10)}$.

Comments. The evaluation of the distal esophagus intercellular space dimensions increases the probability of diagnostic certainty and also allows the analysis of the therapeutic response. The diagnosis by electronic microscopy, however, is costly and not easily available. On the other hand, the diagnosis of intercellular space dilation by optical microscopy is not always feasible.

\section{9) What is the importance of the basal proliferation of the lamina propria in the diagnosis of GERD? \\ Grade A recommendation}

In the combined assessment of the histological alterations for the diagnosis of GERD, the basal layer cell hyperplasia as an isolated alteration has a SB and SP of $98 \%$ and $45 \%$, respectively, with a positive LR of 1.78 and a negative LR of 0.04 . It has, therefore, more importance when it is absent, to rule the diagnosis or active disease ${ }^{(149)}$.

\section{Grade $B$ recommendation}

The 12-month follow-up of patients with GERD undergoing treatment with PPI (lansoprazole, $30 \mathrm{mg}$ /day for 8 weeks, followed by long-term treatment with lansoprazole $15 \mathrm{mg} /$ day or omeprazole $20 \mathrm{mg} /$ day) demonstrates, through esophageal biopsy, that there is a decrease in the basal lamina hyperplasia from $51 \%$ to $2 \%$ as well as an increase of the normal epithelium from $8 \%$ to $63 \%{ }^{(129)}$. When analyzing the role of the presence of basal cell hyperplasia through the assessments of SB (35\%) and SP (71\%), it was verified that there is little impact in the establishment of GERD diagnosis (positive and negative LR of 1.2 and 0.91 , respectively) ${ }^{(33)}$.

Comment. Esophageal biopsies in patients with suspected GERD for the analysis of basal cell proliferation allow, in absence of the latter, ruling out the diagnosis or active disease. The isolated presence of the basal layer proliferation, however, has little diagnostic value. Although the basal cell thickness allows the analysis of the therapeutic response, it is not correlated with the clinical response.

\section{0) What is the importance of the endoscopic ultrasound imaging in the diagnosis of GERD? Grade $B$ recommendation}

When assessed by endoscopic ultrasound imaging, there is a significant difference in the thickness of the esophageal wall between patients with erosive and non-erosive GERD, with a distant involvement of the lesions. There is no correlation between the time of symptom occurrence and degree of thickness ${ }^{(12)}$. In patients with erosive GERD, there is a correlation between the structural alterations of the lower esophageal wall identified by the endoscopic ultrasound and functional impairment of the esophageal pressure ${ }^{(61)}$.

Comments. The available scientific information on the use of endoscopic ultrasound for the diagnosis of structural alterations of the esophageal wall in patients with GERD is restricted and little convincing. With this purpose, therefore, the examination has no clinical applicability.

\section{1) Should patients with asthma be investigated for GERD?}

Grade $A$ recommendation

The prevalence of symptoms of gastroesophageal reflux in asthmatic patients can be of $82 \%$. The symptoms of reflux have a SB of $92 \%$ and a SP of $35 \%$ in the diagnosis of GERD in asthmatic patients with and without altered esophageal $\mathrm{pH}$ (positive LR and negative LR of 1.41 and 0.22$)^{(26)}$. The treatment with pantoprazole ( $40 \mathrm{mg} /$ day) for 12 weeks resulted in symptom and quality of life improvement, with no impact on the respiratory function test in patients with asthma and respiratory symptoms related to gastroesophageal reflux ${ }^{(26)}$. The use of lansoprazole $(30 \mathrm{mg} / 2 \mathrm{x} /$ day $)$ for 24 weeks in patients with asthma and gastroesophageal reflux decreases the risk of asthma exacerbation by $12.3 \% 0^{(72)}$.

\section{Grade $B$ recommendation}

Frequent regurgitation $(>1 /$ week) or excessive reflux in the proximal esophagus ( $>1.1$ of the total time of the doublechannel pH-metry) can predict an improvement of $20 \%$ in asthma symptoms with the daily use of omeprazole (20, 40 or $60 \mathrm{mg} /$ day) for 3 months, with a SB of $100 \%$ and SP of $44 \%$ and that reflects on the certainty of response with a positive LR of 1.78 and a negative LR of $0.0^{(48)}$. 
Comments. The presence of reflux symptoms in asthmatic patients results in a small increase in the probability of diagnostic certainty. In asthmatic patients with reflux symptoms, the normal $\mathrm{pH}$-metry can predict the absence of therapeutic response with PPI. A significant number of patients with asthma (57\%) also present gastroesophageal reflux.

\section{2) Should patients with pulmonary interstitial disease (idiopathic pulmonary fibrosis) be investigated for GERD? \\ Grade A recommendation}

The gastroesophageal reflux is present in $67 \%$ of the patients with idiopathic pulmonary fibrosis. Typical reflux symptoms confer a SB of $65 \%$ and a SP of $71 \%$ for the diagnosis of GERD. The positive and negative LR are 2.24 and 0.49 , respectively ${ }^{(131)}$. The prevalence of GERD in patients with idiopathic interstitial fibrosis (IIF) can be $87 \%$ and only $47 \%$ of these patients presented reflux symptoms ${ }^{(107)}$. Patients with IIF can present more reflux in the distal region of the esophagus than patients with asthma $(76 \% \text { vs } 57 \%)^{(107)}$.

\section{Grade $B$ recommendation}

The risk of the presence of GERD in patients with pulmonary fibrosis can be $94.1 \%$, when compared to that of patients without fibrosis (50\% risk). Only $25 \%$ of these patients have typical symptoms of reflux ${ }^{(133)}$.

Comments. The association between pulmonary fibrosis and GERD is high, although the typical symptoms of reflux increase little the probability of diagnostic certainty in these patients. Patients with idiopathic pulmonary fibrosis must be investigated regarding the occurrence of acid reflux.

\section{3) Should patients with sleep disorders and/or apnea be investigated for GERD? \\ Grade $B$ recommendation}

Patients with sleep apnea have more acid reflux events in 8 hours than patients without sleep apnea, as well as a longer time of $\mathrm{pH}<4.0$ during the esophageal $\mathrm{pH}$-metry. In patients with sleep apnea, $53.4 \%$ of the reflux episodes are related to the apnea and hypopnea and $46.8 \%$ of all apneas are related to episodes of reflux ${ }^{(50)}$.

When the GERD symptom Assessment Score and the Sleep Heart Health Study Sleep Habits questionnaire were applied, a positive association between sleep disorders and the severity of the index of symptoms was observed ${ }^{(45)}$. A higher number of awakenings during sleep is also associated with higher symptom indexes of GERD. A worse-quality sleep was associated to a higher number of episodes of reflux at the $\mathrm{pH}-$ metry ${ }^{(24)}$. In patients with sleep apnea, around $81 \%$ of the all acid events are associated to respiratory events (apnea or hypopnea), although there was no correlation between the events and the magnitude of the apnea-hypopnea index ${ }^{(8)}$. In patients with sleep apnea, retrosternal pyrosis or regurgitation is not related to the severity of apnea ${ }^{(24)}$.

Comments. There is an association between GERD and sleep apnea and/or disorders. Patients with sleep apnea and/ or disorders must be investigated regarding the occurrence of acid reflux.

\section{4) Should patients with signs that are suggestive of posterior laryngitis be investigated for GERD? Grade $A$ recommendation}

The symptoms of posterior chronic laryngitis ("throatcleaning", coughing, globus, sore throat and hoarseness) do not significantly improve with the use of esomeprazole $\left(40 \mathrm{mg} /\right.$ day) for 16 weeks, when compared to a placebo ${ }^{(137)}$. A 12-week treatment with lansoprazole $(30 \mathrm{mg} /$ day $)$ did not result in any difference in the number of patients with chronic laryngitis that presented a partial or total symptom resolution when compared to the placebo ${ }^{(26)}$.

\section{Grade $B$ recommendation}

There is no correlation between the symptoms of chronic laryngitis and the degree of laryngeal acid reflux. The heartburn was considered worse in a group of patients with laryngeal reflux than in those without reflux. The patients with laryngeal reflux presented more distal reflux (number of episodes and percentage of time with $\mathrm{pH}<4$ at the esophageal pH-metry assessment) than the patients without laryngeal reflux ${ }^{(99)}$. The isolated comparison of the symptoms of chronic laryngitis with the $\mathrm{pH}$-metry assessment for the diagnosis of GERD supplies an insufficient LR to increase the diagnostic certainty (Table 1$)^{(34)}$.

\begin{tabular}{lcccc}
\multicolumn{5}{c}{ TABLE } \\
1. Symptoms of laryngitis do not allow diagnostic certainty \\
\hline Symptoms & Sensitivity (\%) & Specificity $(\%)$ & positive $\boldsymbol{P}$ & negative $\boldsymbol{P}$ \\
\hline Coughing & 31 & 53 & 0.65 & 1.30 \\
Globus & 3 & 91 & 0.33 & 1.06 \\
Hoarseness & 44 & 67 & 1.35 & 0.82 \\
Sore throat & 10 & 88 & 0.83 & 1.02 \\
\hline
\end{tabular}

Comments. The response to the therapeutic test with PPI in patients with manifestations of chronic laryngitis does not increase the diagnostic probability of GERD. The symptoms of laryngitis, which are typical of gastroesophageal reflux, occur dissociatively from the frequency and intensity of the acid reflux; moreover, the possibility of non-acid and weakly acid reflux is also possible. The patients with chronic laryngitis must be investigated regarding the possibility of reflux.

\section{5) What is the contribution of the therapeutic test with PPI to the diagnosis of GERD? \\ Grade A recommendation}

The symptomatic response $(86.4 \%)$ after 4 weeks of empiric treatment with esomeprazole $(40 \mathrm{mg} /$ day $)$ in patients with GERD is equivalent to the treatment preceded by UDE $(87.5 \%)^{(39)}$. The omeprazole test $(40 \mathrm{mg} /$ day $)$ in patients with GERD diagnosed through $\mathrm{pH}$-metry, results in a SB of $68 \%$ and a SP of $63 \%$, with a positive and negative LR of 1.83 and 0.50 , respectively ${ }^{(117)}$. The sensibility of the rabeprazole test $(20 \mathrm{mg} / \mathrm{day}$, for 1 week), compared to the diagnosis of GERD by UDE and/or pH-metry, results in a SB of $83 \%$, 
SP of $45 \%$, positive LR of 1.5 and negative LR of 0.37 . The $\mathrm{SB}, \mathrm{SP}$, positive LR and negative LR of the placebo group were $40 \%, 67 \%, 1.2$ and 0.89 , respectively ${ }^{(22)}$.

Comments. Although the aforementioned studies have a satisfactory level of evidence, they are heterogeneous regarding the employed PPI, used doses, time of observation and therapeutic response assessment. Thus, certain patients with GERD might nor present a positive response to the diagnostic test, eventually, because they would need a higher dose or a longer period of the test treatment. In certain patients with suspected GERD, however, the diagnostic contribution of the therapeutic test with PPI is satisfactory.

\section{MANAGEMENT}

The primary treatment objectives are the alleviation of symptoms, the healing of mucosal lesions, when they are present, and the prevention of recurrence and complications. The treatment can be considered as being clinical, surgical or endoscopic. From a practical point of view, the therapeutic approach can be divided into behavioural and pharmacologic measures. It is important that the patient is made aware that he or she has a chronic disease.

\section{1) During the treatment of GERD, should the PPI drugs (omeprazole, lansoprazole, pantoprazole, rabeprazole, esomeprazole) be taken as a single daily dose or twice daily? \\ Grade $A$ recommendation}

In patients with the erosive form of the disease, the use of rabeprazole, $10 \mathrm{mg} / \mathrm{day}$, taken in two daily doses for 8 weeks, when compared to rabeprazole $20 \mathrm{mg} /$ day taken as a single daily dose, did not increase the number of patients with endoscopic improvement and increased the severity of symptoms on the $3 \mathrm{rd}$ day of treatment ${ }^{(21)}$. The response to the treatment with esomeprazole, $40 \mathrm{mg} /$ day taken as a single dose or $20 \mathrm{mg} /$ day taken twice a day for 12 days is similar, when assessed by esophageal pH-metry and UDE ${ }^{(53)}$. The response to the treatment of patients with a GERD diagnosis established by esophageal pH-metry and UDE, with esomeprazole $20 \mathrm{mg}$ /day taken in two daily doses or $40 \mathrm{mg} /$ day taken as a single daily dose for a period of 2 weeks, is $79 \%$ and $86 \%$, respectively, with no statistical difference ${ }^{(54)}$.

Comments. There is no difference regarding the clinical response to the treatment with PPI taken as two daily doses, when compared to a single daily dose.

\section{2) During GERD treatment, should the histamine H2 receptor antagonists (H2-RA: cimetidine, ranitidine, famotidine, nizatidine) be associated to PPI? \\ Grade $A$ recommendation}

The addition of H2-RA to the PPI treatment leads to the improvement in the general symptoms of GERD in 28/39 $(72 \%)$ of the patients and in $18 / 27(67 \%)$ of the patients with nocturnal reflux symptoms ${ }^{(106)}$. The administration of PPI (omeprazole, $40 \mathrm{mg}$ /day) associated to a H2-RA (ranitidine, $300 \mathrm{mg} /$ day) significantly reduces $(P<0.001)$ the percentage of time of gastric $\mathrm{pH}<4$ for the supine period, when compared to PPI, alone (omeprazole, $40 \mathrm{mg} /$ day), with no difference between a single daily dose or two daily doses taken for a period of 30 days $^{(30)}$. The addition of low-dose ranitidine $(75 \mathrm{mg} /$ day) helps in the control of nocturnal gastric acidity, which can occur during the conventional administration of omeprazole ${ }^{(112)}$. The mean value of the percentage of time during which the intragastric $\mathrm{pH}$ was $<4$ in the supine position with omeprazole ( $20 \mathrm{mg}$, twice a day) was $18 \%$, when compared to $29.7 \%$, when a combination of omeprazole + ranitidine $(150 \mathrm{mg} /$ day $)$ was administered, with a $P=0.003^{(62)}$.

\section{Grade $B$ recommendation}

Question included in the panel through the indication of participants after voting (level of agreement: 90\%).

Comments. The use of H2RA associated to PPI apparently helps in the nocturnal acid control, leads to an improvement in the nocturnal symptoms of reflux and sleep disorders. It is important to remember, however, that the level of evidence is $2 \mathrm{~b}$, with cross-sectional, historical cohort, non-randomized studies. Thus, a reasonable degree of uncertainty persists regarding the use of $\mathrm{H} 2 \mathrm{RA}$ at night added to the PPI.

\section{3) Should the treatment of GERD consist in the administration of a full dose of PPI for a period of 8 weeks? \\ Grade A recommendation}

In patients with non-erosive GERD, the nocturnal heatburn was treated with esomeprazole, $40 \mathrm{mg} / \mathrm{day}, 20 \mathrm{mg} /$ day or placebo, for a period of 4 weeks with satisfactory results in $53.1 \%, 50.5 \%$ and $12.7 \%$, respectively. The difference between esomeprazole $40 \mathrm{mg}$, esomeprazole $20 \mathrm{mg}$ and placebo was $40.5 \%$ and $37.8 \%$, respectively, with a $L R=2$ in both treatments ${ }^{(51)}$. The analysis of the dairy of symptoms in patients with non-erosive GERD indicates that, after 8 weeks of treatment with lansoprazole $30 \mathrm{mg} /$ day or $15 \mathrm{mg} /$ day, the persistence of nocturnal heartburn was present in $49 \%$ and $39 \%$ of the patients, respectively. When compared to the placebo response, there was a decrease in the risk of the presence of nocturnal hearburn in $19.3 \%$ and in $29.2 \%$ of the patients, respectively. Similarly, the daytime heartburn presented a decrease in the symptom index with the use $15 \mathrm{mg} / \mathrm{day}$ and $30 \mathrm{mg} /$ day of $19.3 \%$ and $24.6 \%$, respectively ${ }^{(108)}$. In patients with erosive GERD, the rates of healing with omeprazole $40 \mathrm{mg} /$ day and $20 \mathrm{mg}$ /day for 4 weeks were $41 \%$ and $26 \%$, with a difference of $15 \%{ }^{(109)}$. The rates of erosive esophagitis resolution in 4 weeks, with the use of pantoprazole $20 \mathrm{mg} /$ day and $40 \mathrm{mg}$ /day were $55 \%$ and $72 \%$, respectively, which, compared to the placebo, results in a decrease in the risk of esophagitis of $40.6 \%$ and $57.7 \%$, respectively ${ }^{(109)}$. The decrease in the risk of erosive esophagitis in 8 weeks with the use of pantoprazole $20 \mathrm{mg} /$ day and $40 \mathrm{mg} /$ day was $45.3 \%$ and $55.5 \%$, respectively ${ }^{(109)}$. The treatment of patients with non-erosive GERD with rabeprazole $10 \mathrm{mg} /$ day or $20 \mathrm{mg} /$ day for 4 weeks decreases the 
risk of pyrosis persistence by $25.2 \%$ and $25.5 \%$, respectively. It also decreases the risk of dissatisfaction with symptom improvement by $23.8 \%$ and $24.3 \%{ }^{(59)}$.

Comments When the PPI were used in full dose (esomeprazole: $20 \mathrm{mg} /$ day and $40 \mathrm{mg} /$ day; lansoprazole: $15 \mathrm{mg} /$ day and 30 $\mathrm{mg}$ /day; omeprazole: $40 \mathrm{mg} /$ day; pantoprazole $20 \mathrm{mg} /$ day and $40 \mathrm{mg} /$ day; rabeprazole: $10 \mathrm{mg} /$ day and $20 \mathrm{mg} /$ day), no statistical difference was observed between 4 and 8 weeks of treatment. Nevertheless, in cases of therapeutic failure, the time of treatment can be extended from 4 to 8 weeks, as although no significant difference was observed between the two periods, the number of satisfactory responses is higher after 8 than after 4 weeks.

\section{4) During the treatment of GERD, is the therapeutic response to the different $\mathrm{PPI}$ equivalent? Grade $A$ recommendation}

- Esomeprazole (40 mg/day) and pantoprazole (40 mg/day).

- Pantoprazole and esomeprazole were equivalent regarding symptom improvement (ReQuest scale) for 4-week treatments. Symptom recurrence after 7 days of treatment ( $51 \%$ versus $61 \%$ ) and the number of symptomatic episodes (0.56 vs $0.74, P=0.0095)$ was lower with pantoprazole when compared to esomeprazole ${ }^{(43)}$. The number of patients with esophagitis improvement was higher with esomeprazole than with pantoprazole in a 4-week period $(81 \%$ vs $75 \%)$ and a 8 -week period $(96 \% \text { vs } 92 \%)^{(69)}$. The improvement of esophagitis is equivalent with the use of pantoprazole or esomeprazole as a full dose during 10 weeks ( $88 \%$ in both treatments). The number of patients presenting symptom improvement was also similar $(50 \%$ and $47 \%$ - with no statistical difference, respectively) ${ }^{(40)}$. After a 4-week treatment period, the number of patients reporting symptom resolution was similar in the two groups of treatment (pantoprazole $=99 \%$ and esomeprazole $=$ $98 \%)^{(120)}$. Regarding the persistence of symptom resolution in patients with non-erosive GERD, there is no difference between pantoprazole ( $20 \mathrm{mg} /$ day $)$ and esomeprazole (20 mg/day), during a 14-day treatment period $(56.4 \%$ vs $54.4 \%)$ or a 28 -day one $(80.2 \% \text { vs } 79.4 \%)^{(91)}$.

- Esomeprazole (20/40 mg/day) and omeprazole (20 mg/ day).

After an 8-week treatment with esomeprazole-20 mg/ day $(90.6 \%)$ and omeprazole-20 $\mathrm{mg} /$ day $(88.3 \%)$, the rates of esophagitis healing were equivalent ${ }^{(71)}$. A higher number of patients presented esophagitis resolution after treatment with esomeprazol-40 mg/day $(75.9 \%)$ in comparison with omeprazol-20 mg/day (64.7\%), during a 4-week treatment and an 8-week treatment period (respectively, 94.1\% vs $86.9 \%$ ). The use of esomeprazole $20 \mathrm{mg} /$ day also resulted in a higher number of patients with esophagitis resolution only in the 4 th week of treatment $(70.5 \% \text { vs } 64.7 \%)^{(58)}$. The number of patients with GERD that presented healing with esomeprazole-40 mg/day when compared to omeprazole-20 $\mathrm{mg} /$ day was similar at 4 weeks $(71.5 \%$ vs $68.6 \%)$ and at 8 weeks $(92.2 \% \text { vs } 89.8 \%)^{(119)}$.
- Esomeprazole (40 mg/day) and lansoprazole (30 mg/day).

In the resolution of reflux esophagitis, the treatment with esomeprazole was superior to that with lansoprazole during a 4-week (58.6\% vs 49.4\%, respectively) and an 8 week period $(82.4 \% \text { vs } 77.5 \% \text { of duration, respectively })^{(31)}$. In patients with erosive esophagitis, the treatment with esomeprazole is superior to that with lansoprazole, with a healing rate in 4 weeks of $79.4 \%$ vs $75.1 \%$, respectively and in 8 weeks of $92.6 \%$ vs $88.8 \%$, respectively ${ }^{(15)}$.

- Pantoprazole (40 mg/day) and omeprazole (40 mg/day).

The percentage of patients that presented healing of the esophagitis during treatments with pantoprazole and omeprazole after $8(84.3 \%$ and $84.9 \%)$ and 4 weeks $(65.3 \%$ and $66.3 \%$ ) was equivalent ${ }^{(67)}$.

- Rabeprazole (20 mg/day) vs omeprazole (20 mg/day).

After 4 and 8 weeks of treatment, the resolution of the esophagitis obtained with rabeprazole and omeprazole was equivalent, with the rates varying around $81 \%$ for both treatments at 4 weeks and $92 \%$ and $94 \%$ at 8 weeks, respectively ${ }^{(20)}$.

- Lansoprazole (30 mg/day) vs omeprazole (20 mg/day) and/ or pantoprazole (40 mg/day). Lansoprazole is similar to omeprazole and pantoprazole regarding the improvement of pyrosis after 4 or 8 weeks of treatment ${ }^{(95)}$. There is no difference regarding the rates of pyrosis resolution in patients with erosive esophagitis, when treated with lansoprazole or omeprazole at 4 weeks $(77.2 \%$ vs $76.2 \%)$ or at 8 weeks $(84.3 \% \text { vs } 83.0 \%)^{(110)}$.

- Rabeprazole (10 mg/day) vs esomeprazole (20 mg/day).

Concerning the treatment of non-erosive GERD, the time necessary to obtain a symptom-free period of 24 hours (pyrosis or regurgitation) is similar when using rabeprazole or esomeprazole. Moreover, when considering the global symptom improvement reported by the patients, rabeprazole and esomeprazole present similar results $(96.0 \%$ vs $87.9 \%$ - not significant) ${ }^{(32)}$.

Comments. Esomeprazole 20/40 mg/day, lansoprazole 30 $\mathrm{mg}$ /day, omeprazole 20/40 mg/day, pantoprazole $40 \mathrm{mg} /$ day and rabeprazole $20 \mathrm{mg}$ /day are equivalent in the treatment of patients with erosive GERD. Esomeprazole 20/40 mg/ day, omeprazole $20 \mathrm{mg}$ /day, pantoprazole $20 \mathrm{mg} /$ day and rabeprazole $10 \mathrm{mg} /$ day are equivalent in the treatment of patients with non-erosive GERD.

\section{5) Should a prokinetic agent (domperidone, mosapride, cisapride) be added to the PPI treatment of GERD ?}

\section{Grade A recommendation}

In patients with heartburn and/or regurgitation symptoms, there is no difference $(P=0.11)$ in the response of symptoms to the treatment with pantoprazole $(40 \mathrm{mg} /$ day) in comparison with the association of pantoprazole and mosapride $(5 \mathrm{mg} / 3 \mathrm{x}$ day): $69.7 \%$ vs $89.2 \%$, respectively. The score of symptoms after 8 weeks was significantly lower $(P=0.009)$ in patients that 
used the association $(3.78 \pm 3.62$ vs $1.67 \pm 2.09)$. In patients with non-erosive GERD, there was no significant difference $(P=0.63)$ between the two types of treatment (pantoprazole: $17 / 20$ and pantoprazole + cisapride: $7 / 9$ ). In cases of erosive esophagitis, the symptomatic response occurred more frequently $(P=0.003)$ with the association $(18 / 19-94.7 \%)$ than in cases in which pantoprazole was employed exclusively $(6 / 13-46.2 \%)$. The endoscopic resolution of the esophagitis, however, occurred similarly $(P>0.005)$ with both regimens (pantoprazole: $6 / 11,54.5 \%$ and association: $12 / 17,70.5 \%)^{(79)}$. The therapeutic outcome in asthmatic patients with GERD (diagnosed by 24-hour $\mathrm{pH}$-metry) treated with the association between omeprazole, $20 \mathrm{mg} / 2 \mathrm{x}$ day + domperidone, $10 \mathrm{mg} / 3 \mathrm{x}$ day, when compared to the placebo, showed a significant decrease $(P<0.001)$ in the score of daytime symptoms of asthma $(17.4 \%$ vs $8.9 \%)$, in the score of symptoms of reflux $(8.7 \%$ vs $1.6 \%)$ and in the use of rescue medication $(23.2 \%$ vs $3.1 \%)^{(123)}$. Considering the therapeutic plans: omeprazole ( $20 \mathrm{mg} /$ day) and the association between omeprazole ( $20 \mathrm{mg} /$ day) and cisapride $(30 \mathrm{mg} / \mathrm{day})$, the number of patients that persisted with symptom remission at the 12-month followup was: omeprazole $=28 / 35(80 \%)$ and association $=31 / 35$ $(89 \%)$. The therapeutic plan consisting of omeprazole + cisapride was significantly more effective $(P=0.003)$ than cisapride alone $\mathrm{e}^{(140)}$.

Comments. The outcome of the association between prokinetic agents and PPI in the treatment of erosive and non-erosive GERD is not conclusive. On the other hand, the prokinetic agents available in our country (domperidone, bromopride and metoclopramide) have not been conveniently and consistently studied regarding their use associated to PPI in these patients.

\section{6) Can the long-term use of PPI cause damage to the gastric mucosa?}

Grade $A$ recommendation

During 7 years of observation, the patients with GERD that remained negative for the presence of $H$. pylori did not present histological signs of gastric disease. In patients positive for the presence of $H$. pylori, the use of omeprazole $20 \mathrm{mg} /$ day for 7 years resulted in glandular atrophy, which was not verified in patients submitted to the surgical intervention ${ }^{(77)}$. An increase in enterochromaffin cell hyperplasia of the oxyntic mucosa was observed in patients with GERD positive for $H$. pylori after the chronic use of omeprazole $20 \mathrm{mg} /$ day for 5 years, when compared to rabeprazole $10 \mathrm{mg} /$ day or $20 \mathrm{mg} /$ day $^{(111)}$. In patients with GERD and the presence of $H$. pylori, the use of omeprazole $40 \mathrm{mg} /$ day for a period of 12 months determined a pattern of gastric antral mucosa atrophy, when compared to those submitted to the eradication ${ }^{(89)}$. After a 1-year period of omeprazole use ( $40 \mathrm{mg} /$ day), the prevalence of protrusion of parietal cells increased from $18 \%$ to $86 \%(P<0.001)$, regardless of the $H$. pylori eradication. The prevalence of cysts in the fundic glands, however, increased from $8 \%$ to $35 \%(P<0.05)$, being more prevalent in patients submitted to $H$. pylori eradication $(P<0.05)^{(16)}$.
Comments. The report of the occurrence of neoplasia with the chronic use of PPI is not supported by evidence. The gastric mucosa, however, is altered in these conditions (chronic gastritis, atrophy and polyps of fundic glands). The prevalence of gastric atrophy signs increases along the years, mainly when $H$. pylori is present.

\section{7) Should $H$. pylori be eradicated in patients with GERD? Should the eradication of $\boldsymbol{H}$. pylori be carried out in patients who are chronic users of PPI? \\ Grade A recommendation}

The rate of GERD symptom recurrence in 1 year is not different in patients submitted or not to the eradication of H. pylori ${ }^{(90)}$. In patients with GERD, the eradication of $H$. pylori (amoxicillin $2 \mathrm{~g} /$ day + clarithromycin $1 \mathrm{~g} /$ day) is as high as $88 \%$, with a decrease in gastric inflammation in 2 years, without altering the presence of GERD symptoms or the need for the chronic use of omeprazole ( $40 \mathrm{mg} /$ day) ${ }^{(68)}$. In patients with GERD, after a 12-month follow-up, the probability of therapeutic failure regarding the symptoms is higher in patients that underwent the eradication of $H$. pylori $(43.2 \%)$ than in those that did not $(21.1 \%)^{(148)}$. Throughout 1 year of omeprazole use ( $40 \mathrm{mg} /$ day) for the treatment of GERD, the signs of chronic inflammation were decreased when compared to those patients who did not undergo $H$. pylori eradication ${ }^{(90)}$.

Comments. At the long-term ( $>1$ year), the eradication of H. pylori in patients with GERD does not reduce the presence of symptoms or the rates of recurrence of the disease, although it decreases the histological signs of gastric inflammation. Therefore, it seems likely there is no association between $H$. pylori eradication and GERD manifestations.

\section{8) In patients with atypical manifestations, what is the time of treatment and PPI dose that should be employed? \\ Grade $A$ recommendation}

In asthmatic patients, lansoprazole, $30 \mathrm{mg} / 2 \mathrm{x}$ day for 6 month decreased the risk of symptom exacerbation ${ }^{(72)}$. Pantoprazole, $40 \mathrm{mg} /$ day for 3 months did not improve the score of symptoms and pulmonary function, although it improved the quality of life score ${ }^{(116)}$. Pantoprazole, $40 \mathrm{mg} /$ day for 3 months in asthmatic patients did not improve the score of symptoms of reflux, as well as did not decrease the number of patients with altered esophageal $\mathrm{pH}$-metry ${ }^{(147)}$. In patients with bronchial hyperreactivity, the use of omeprazole, $40 \mathrm{mg} / 2 \mathrm{x}$ day for 3 months, reduced the risk of pyrosis and the esophageal $\mathrm{pH}$-metry assessment ${ }^{(82)}$. In patients with laryngitis, esomeprazole, $40 \mathrm{mg} /$ day for 4 months did not improve the time of $\mathrm{pH}<4$ and the score of quality of life, of symptoms and of GERD ${ }^{(137)}$. Lansoprazole $30 \mathrm{mg} / 2 \mathrm{x}$ day for 3 months in patients with laryngitis promoted improvement of GERD symptoms ${ }^{(26)}$. Lansoprazole $30 \mathrm{mg} /$ day compared to lansoprazole $30 \mathrm{mg} / 2 \mathrm{x}$ day for a period of 3 months did not promote improvement of GERD symptoms of the VAT scale in patients with chronic cough and did not reduce the number of patients with symptoms ${ }^{(6)}$. The use of omeprazole, 
$20 \mathrm{mg} / 2 \mathrm{x}$ day for $2 \mathrm{months}$ in patients with non-cardiac thoracic pain increases the probability of symptom improvement and reduces the number of days with pain ${ }^{(1)}$.

Comments. The cases of acid reflux and atypical manifestations (asthma, bronchial hyperactivity, laryngitis and non-cardiac thoracic pain) respond better to a double dose of PPI for longer periods (2 to 6 months).

\section{9) Is there any equivalence among the PPIs in the response to GERD maintenance therapy? Grade A recommendation}

- Esomeprazole (20 mg/day) and pantoprazole ( $20 \mathrm{mg} /$ day). At 6 months of maintenance treatment of erosive GERD, pantoprazole and esomeprazole showed the same rate of symptom remission $(84 \% \text { and } 85 \% \text {, respectively })^{(44)}$.

- Esomeprazole $(20 \mathrm{mg} /$ day $)$ and lansoprazole $(15 \mathrm{mg} /$ day). At 6 months of follow-up, the number of patients with erosive GERD presenting endoscopic remission was higher among those treated with esomeprazole than in those treated with lansoprazole $(84.8 \%$ versus $75.8 \%)$. No difference was observed between the occurrence of pyrosis (23.6\% vs $26.2 \%)$ and regurgitation ( $20 \%$ in both regimens) ${ }^{(23)}$. At 6 months of follow-up, esomeprazole showed a higher proportion of patients in remission than lansoprazole ( $83 \%$ vs $74 \%$, respectively) ${ }^{(70)}$.

- Rabeprazole (10 mg/day) and omeprazole $(20 \mathrm{mg} /$ day). The use of rabeprazole $(10 \mathrm{mg} /$ day and $20 \mathrm{mg} /$ day $)$ was equivalent to omeprazole in the maintenance of esophagitis resolution in 52 weeks $^{(132)}$.

- Lansoprazole (30 mg/day) and omeprazole ( $20 \mathrm{mg} /$ day). The follow-up of patients with erosive esophagitis during 6 months showed that $3.7 \%$ and $5 \%$, respectively, presented therapeutic failure with lansoprazole and omeprazole $^{(52)}$. In patients that presented recurrence of the disease (evaluated by symptoms and/or presence of erosions at the endoscopic assessment), no difference was observed, regarding the proportion of patients, between the two types of treatment: lansoprazole $(9.5 \%)$ and omeprazole $(9 \%)^{(14)}$.

Comments. During the observed period of 6 months, in the maintenance treatment of patients with erosive GERD, the PPI presented equivalent therapeutic response. The following PPI were studied: esomeprazole ( $20 \mathrm{mg} /$ day), pantoprazole (20 mg/day), omeprazole ( $20 \mathrm{mg} /$ day), lansoprazole (15 and $30 \mathrm{mg} /$ day $)$, rabeprazole (10 mg/day).

\section{0) In the treatment of non-erosive GERD should the maintenance treatment with PPI be performed continuously, intermittently or upon demand? Grade A recommendation}

The use of esomeprazole $20 \mathrm{mg} /$ day upon demand, when compared to lansoprazole $15 \mathrm{mg} / \mathrm{day}$, used continuously, reduces the risk of treatment discontinuity due to worsening of symptoms in 7\% and adverse events (headaches and diarrhea) in $6.4 \%{ }^{(135)}$. In patients with GERD symptoms, the treatment upon demand with esomeprazole $20 \mathrm{mg} /$ day, compared to the intermittent treatment with esomeprazole
$40 \mathrm{mg} / \mathrm{day}$, did not increase the patients' degree of satisfaction, but decreased the number of symptom recidivisms in 6 months ${ }^{(88)}$.

Comments. During the observed period of 6 months, the treatment upon demand is preferable to the continuous or intermittent treatment, with clinical and economical advantages. The following PPI were studied: esomeprazole (20 and $40 \mathrm{mg} /$ day) and lansoprazole $(15 \mathrm{mg} / \mathrm{day}$ ).

Note. One of the steps of the clinical treatment of GERD is related to the non-pharmacological management: lifestyle modifications or behavioural measures, which are presented in Figure 1.

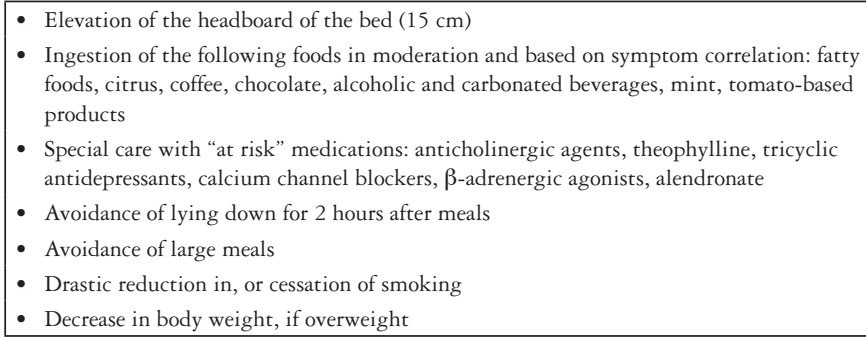

FIGURE 1. Behavioural modifications in the treatment of GERD ${ }^{(92)}$

\section{1) Does the non-pharmacological therapy (behavioral measures) produce results in the treatment of GERD?}

Grade $B$ recommendation

Question included in the panel through the indication of the participants after voting (level of agreement: $92 \%$ ).

\section{a) Elevation of the headboard of the bed $(15 \mathrm{~cm})$}

To sleep with a wedge-shaped support is associated with a lower acid exposition than in the horizontal position ${ }^{(47)}$. The elevation of the headboard $(28 \mathrm{~cm})$ reduces the number of reflux episodes and time of acid exposition with a $\mathrm{pH}<5^{(127)}$.

\section{b) Dietetic factors. Alcoholic beverages}

The habit of consuming sweets and white bread is associated to reflux symptoms ${ }^{(98)}$. The habit of consuming fruit has a protective effect on the reflux symptoms ${ }^{(98)}$. The ingestion of proteins is associated to erosive GERD and the ingestion of fibers to a lower risk of GERD ${ }^{(27)}$. The excessive ingestion of sweets and food is associated with GERD ${ }^{(141)}$. A fat-rich diet does not increase the number of reflux episodes or the esophageal acid exposition ${ }^{(102)}$. The habit of drinking coffee is associated to GERD ${ }^{(141)}$. The ingestion of alcohol is a risk factor for erosive GERD ${ }^{(64)}$. The frequent ingestion of alcoholic beverages constitutes a risk factor for symptoms of reflux ${ }^{(98)}$. The habit of drinking wine or beer increases the risk of reflux ${ }^{(101)}$. The use of alcohol is a risk factor for erosive GERD ${ }^{(114)}$. The ingestion of alcoholic beverages is associated to GERD ${ }^{(141)}$.

c) Posture. Physical exercise. Nocturnal meals

To work in an inclined position constitutes a risk factor for non-erosive GERD ${ }^{(64)}$. Episodes of gastroesophageal reflux 
are triggered by posture ${ }^{(64)}$. Physical activity seems to have a protective effect on GERD ${ }^{(98)}$. A short interval between dinner and bedtime is associated with an increased risk of GERD, especially when $<3$ hours $^{(36)}$. The later the nocturnal meal, the higher is the rate of reflux, especially in obese individuals and patients with erosive GERD ${ }^{(104)}$.

\section{d) Smoking}

Smoking is associated with GERD ${ }^{(64)}$. Smoking is a risk factor for non-erosive GERD ${ }^{(64)}$. Smoking is a risk factor for reflux symptoms ${ }^{(98)}$. Smokers present more episodes of reflux than non-smokers, but the abstinence from smoking for 24 hours does not reduce the time of $\mathrm{pH}<4^{(118)}$. Abstinence from smoking reduces, in 24 hours, the number of reflux episodes, but it does not affect the total acid exposition ${ }^{(142)}$. Smokers, after a 48-abstinence from smoking, present an increase in the esophageal acid exposition ${ }^{(57)}$. Smoking is included among the risk factors for GERD ${ }^{(128)}$.

\section{e) Obesity}

A body mass index (BMI) $\geq 25$ constitutes a risk factor for erosive GERD. The elevated BMI is associated to gastroesophageal reflux ${ }^{(97)}$. The BMI $>25$ constitutes a risk factor for GERD ${ }^{(114)}$. Patients with a BMI of around 42.5 $\mathrm{kg} / \mathrm{m}^{2}$ do not present an association with the prevalence of GERD $^{(75)}$. Obesity is associated with GERD ${ }^{(141)}$. There is an association between the reflux symptoms and obesity ${ }^{(98)}$. Obesity predisposes the individual to gastroesophageal reflux and the loss of weight improves the postprandial reflux and reduces the time of $\mathrm{pH}<4^{(84)}$. The decrease in weight does not reduce the manifestations of gastroesophageal reflux ${ }^{(65)}$.

\section{f) Stress and fatigue}

Stress and fatigue trigger episodes of gastroesophageal reflux ${ }^{(57)}$. Stress is one of the risk factors for GERD ${ }^{(128)}$.

Comments. The non-occurrence of consistent information (evidence level 2 - grade B recommendation) regarding the elevation of the headboard, certain dietetic factors, ingestion of alcohol, physical exercise, inclined posture, smoking, presence of obesity, stress and fatigue does not decharaterize eventual recommendations of behavioral nature assessed in each case. The elevation of the headboard and to maintain an interval between the last meal and bedtime, for instance, are recommended.

\section{2) What are the indications for the surgical treatment of GERD? \\ Grade $B$ recommendation}

Question included in the panel through the indication of the participants after voting (level of agreement: 93.6\%).

\section{a) Hiatal hernia. Paraesophageal hernia. Risk factors. Prognosis.}

The laparoscopic Nissen fundoplication is equally effective in patients with GERD or with paraesophageal hernia ${ }^{(83)}$. During a mean follow-up of 72 months, $93 \%$ of the patients with large paraesophageal hernias presented free of symptoms related to GERD ${ }^{(86)}$. Hiatal hernias $<3 \mathrm{~cm}$ constitute a risk factor for non-erosive GERD and those $>3 \mathrm{~cm}$, for erosive GERD and Barret's esophagus ${ }^{(122)}$. The dimensions of the hiatal hernia, decreased pressured in the lower esophageal sphincter, esophageal acid exposition and the number of reflux episodes are associated with the degree of severity of the esophagitis ${ }^{(55)}$. Hiatal hernias $>2 \mathrm{~cm}$ are associated with erosive GERD and Barret's esophagus ${ }^{(13)}$. The presence of a hiatal hernia is associated with more severe esophagitis and predisposes patients with non-erosive GERD to more severe histological alterations ${ }^{(35)}$. The hiatal hernia constitutes a risk factor for the occurrence of erosive GERD ${ }^{(64)}$. The recurrence of symptoms after the fundoplication (Nissen or Toupet) is higher in larger hernias (grades 3 and 4$)^{(28)}$. In patients with GERD and hiatal hernia (where $31 \%$ presented erosive GERD and 75\% presented lower esophageal sphincter dysfunction), the reduction, crural closure and Nissen fundoplication produced, in a 14-month follow-up, symptom improvement ${ }^{(37)}$. Hiatal insufficiency and concentric hiatal hernia are determinant factors of irreversible incontinence of the cardia ${ }^{(85)}$.

Comments. The presence of a hiatal hernia requires higher doses of PPI for the clinical treatment. The presence of permanent migration of the esophagogastric junction and the dimensions of the hiatal hernia $(>2 \mathrm{~cm})$ are factors of worse prognosis of GERD. In this case, hiatal hernias associated with GERD, especially the fixed ones $>2 \mathrm{~cm}$, must be considered for surgical treatment. The results of the laparoscopic fundoplication are adequate.

\section{b) Motility}

Grade $B$ recommendation

Question included in the panel through the indication of the participants after voting (level of agreement: $80.9 \%$ ).

The Nissen fundoplication offers good results in patients with normal esophageal motility and the Toupet fundoplication, in patients with esophageal dysmotility ${ }^{(73)}$. No difference was observed in postoperative symptoms in patients with or without esophageal dysmotility submitted to the fundoplication (Nissen or Toupet) ${ }^{(9)}$. The type of fundoplication must not be determined by the presence of esophageal dysmotility, as the postoperative dysphagia is not related to the dysmotility ${ }^{(130)}$.

Comments. The esophageal dysmotility indicates a more severe disease, does not affect the postoperative outcomes, does not improve with fundoplication and can occur due to the surgical intervention. The surgical treatment should not, therefore, be indicated according to the parameter of esophageal dysmotility. The latter can contra-indicate the surgical treatment.

\section{c) Costs}

\section{Grade $B$ recommendation}

Question included in the panel through the indication of the participants after voting (level of agreement: $74.9 \%$ ).

According to the British National Health System, over a period of 8 years, the laparoscopic fundoplication presents a higher effective cost than the use of PPI ${ }^{(19)}$. Over a period 
of 5 years, the costs with the use of PPI are lower than the open surgery for GERD treatment ${ }^{(96)}$.

Comments. The British Health System observed that the Nissen laparoscopic fundoplication is more cost-effective than the clinical treatment with PPI over an 8-year period. When the open surgery was considered, however, the costs regarding the PPI use over a period of 5 years were lower than those concerning the surgery.

\section{3) What are the results of the clinical treatment vs the surgical treatment of GERD? \\ a) Global outcome \\ Grade A recommendation}

In patients with erosive and non-erosive GERD, the antireflux surgery, in comparison with the anti-reflux treatment with PPI, reduces the time of esophageal $\mathrm{pH}<4$ and improves the VAS score of symptoms, the GERD score and the score of heartburn and regurgitation ${ }^{(3)}$. In patients with chronic erosive GERD, the Nissen surgery, in comparison with PPI use, improves with the score of symptoms, including the digestive one and reduces the time of exposition to $\mathrm{pH}<4^{(80)}$. In patients with chronic erosive reflux disease, Nissen surgery increases the degree of patients' satisfaction when compared to the use of $\mathrm{PPI}^{(87)}$. In patients with chronic erosive reflux disease (symptoms of reflux + esophagitis + previous treatment $>3$ months), the treatment with omeprazole $20 \mathrm{mg}$ or $40 \mathrm{mg}$ was equivalent to the laparoscopic surgical treatment (Nissen), with $93 \%$ and $90 \%$ of the patients, respectively, remaining in symptom remission for 3 years ${ }^{(78)}$. There was a higher incidence of therapeutic failure after the treatment with omeprazole $40 \mathrm{mg}$ or $60 \mathrm{mg}$, than after the surgery (Nissen or Toupet), with the surgery reducing the risk of therapeutic failure by $12.9 \%$. When the clinical and the surgical forms of treatment were compared, however, the scores of symptoms (Gastrointestinal Symptoms Rating Scale - GSRS) and quality of life (Psychological General Well-Being - PGWB) were similar ${ }^{(76)}$.

Comments. There is evidence of the estimated benefit with the surgical treatment when compared to the clinical treatment, with a decrease in therapeutic failure of $12 \%$, with the rates remaining unaltered for an observation period of 7 years. There is also evidence of the same power of equivalence between the clinical treatment with PPI $(93 \%)$ and the Nissen surgical treatment $(90 \%)$, with the patients remaining in symptom remission for 3 years. It would be recommended, however, to have longer periods of observation before a definitive conclusion is reached.

\section{b) Other variables: symptoms, esophagitis and $\mathrm{pH}$; patients' preferences; prognosis; lower esophageal sphincter pressure; stenosis; non-acid GERD}

\section{Grade $B$ recommendation}

Question included in the panel through the indication of the participants after voting (level of agreement: $91 \%$ ).

Over a 12-month follow-up, the clinical and surgical (Nissen) treatments of GERD are effective. The surgery, however, offers an additional benefit in patients that presented a partial improvement with the use of medication, over a mean follow-up period of 6.9 years ${ }^{(87)}$. Over 18 months of observation, the regression of the dysphagia obtained with the Nissen fundoplication $(93.8 \%)$ is higher than that obtained with PPI use $(63.2 \%)^{(115)}$. The laparoscopic surgery for the treatment of GERD improves the quality of life of patients whose symptoms are adequately controlled with the use of PPI ${ }^{(42)}$. In patients submitted to surgery for GERD followed for a period of 5.9 years, $37 \%$ used medication (PPI, H2-RA, anti-acids). Of these, $17 \%$ never discontinued the use and $83 \%$ re-started 2.5 years after the surgery, due to symptom recurrence. The $\mathrm{pH}$-metry was abnormal in $32 \%$ of them ${ }^{(146)}$. After 5 years of observation, no symptom improvement was observed, as well as adverse events or improvement in the score of quality of life among patients with erosive and non-erosive GERD submitted to Nissen laparoscopic fundoplication ${ }^{(60)}$. Heartburn and esophagitis are effectively treated by the clinical and surgical treatments. In these patients, only the surgery improved the regurgitation, dysphagia and esophageal motility ${ }^{(145)}$. Over a period of observation of 12 months, patients with erosive GERD treated with PPI presented a rate of recurrence of $7.7 \%$ when the lower esophageal sphincter pressure was normal $(>8 \mathrm{~mm} \mathrm{Hg})$. The rate of recurrence was $38.1 \%$ when there was sphincter dysfunction and $79.5 \%$ when there was sphincter dysfunction + dysmotility ${ }^{(66)}$. Over a 5 -year period of follow-up, patients with an inadequate response to PPI benefited from undergoing laparoscopic fundoplication, mainly regarding the improvement of quality of life ${ }^{(4)}$. The rate of success of Nissen fundoplication was $75.3 \%$ and was associated with $77.1 \%$ of the patients that responded satisfactorily to the clinical treatment and with $56 \%$ of the patients that did not respond to the clinical treatment ${ }^{(94)}$. During a 10-year follow-up of patients submitted to Nissen fundoplication, the persistence or occurrence of symptoms was $32 \%$, com $68 \%$ of asymptomatic ones. The quality of life remained high, although $80 \%$ were submitted to a new fundoplication procedure ${ }^{(105)}$.

In patients undergoing acid suppression, the episodes of acid reflux were not associated with symptoms, but with the episodes of mixed reflux (liquid-gas) ${ }^{(136)}$. The number of reflux events in the 24 hours after the fundoplication is significantly lower when compared to those in healthy individuals. After the surgery, most episodes of reflux are not acid ones ${ }^{(113)}$. Most of the patients undergoing prolonged treatment with PPI with symptom persistence and a positive symptom index, presented non-acid reflux, including those with atypical symptoms ${ }^{(81)}$.

Comments. There is evidence of estimated benefit with the surgical treatment when compared to the clinical treatment, with a decrease in the therapeutic failure of $12 \%$, with the indices remaining unaltered for an observation period of 7 years. There is also evidence of the same power of equivalence between the clinical treatment with PPI and the Nissen surgical treatment $(90 \%)$, with patients remaining in symptom remission for 3 years. Longer periods of observation would be recommended, however, before a definitive conclusion is attained. 


\section{4) For patients with surgical indication, which fundoplication technique presents better results: total (Nissen) or partial (Toupet)? \\ Grade A recommendation}

After an observation period of 1 year, no differences were observed regarding the presence of pyrosis, regurgitation or other symptoms related to gastroesophageal reflux in patients submitted to Nissen versus Toupet surgery. The Nissen surgery, however, increases the risk of dysphagia of any degree by $18.7 \%$ and thoracic pain at meals by $17.1 \%$. As for the esophageal motility, there was no difference regarding the postoperative symptoms ${ }^{(9)}$. After 2 years of postoperative follow-up, the satisfaction of the patients submitted to surgery through the laparoscopic techniques of Nissen and Toupet is equivalent. The Nissen technique, however, increases the risk of dysphagia by $11 \%{ }^{(130)}$. In patients treated by Nissen technique vs those treated by Toupet, no difference was observed related to the control of pyrosis or acid regurgitation. Also regarding the occurrence of dysphagia, no difference was observed between the two surgical techniques ${ }^{(46)}$. Regarding the recurrence of symptoms, the occurrence of dysphagia or reflux control, there was no difference during the 3-year follow-up after Nissen vs Toupet surgery. The patients submitted to surgeries through the Nissen or Toupet technique were equally satisfied and the reflux control was considered equivalent. The Nissen surgery, however, increased the risk of dysphagia in $19 \%$ of the cases and this finding is not correlated with differences in esophageal motility ${ }^{(150)}$.

Comments. Regarding the therapeutic response, there is no difference between the Nissen and Toupet surgeries. However, the Nissen surgery can produce dysphagia, which is not correlated with motility.

Moraes-Filho JPP, Navarro-Rodriguez T, Barbuti R, Eisig J, Chinzon D, Bernardo W; Grupo Brasileiro de Consenso da Doença do Refluxo Gastroesofágico. Diretrizes para o diagnóstico e tratamento da doença do refluxo gastroesofágico: um consenso baseado em evidências. Arq Gastroenterol. 2010;47(1):99-115.

RESUMO - A doença do refluxo gastroesofágico é uma das enfermidades mais comuns na prática médica. Numerosas diretrizes e recomendações de conduta para seu diagnóstico e tratamento tem sido publicadas em vários países, mas no Brasil ainda não havia sido realizado um trabalho de consenso baseado em padrões de Medicina baseada em evidências. Com esse objetivo, estabeleceu-se um grupo brasileiro representativo de especialistas (Grupo de Consenso da DRGE - doença do refluxo gastroesofágico) para estabelecer diretrizes de conduta de Medicina baseada em evidências para a doença do refluxo gastroesofágico que pudessem ser utilizadas tanto por médicos em cuidados primários de saúde, como por especialistas, seguradoras e agências regulatórias. Foram propostas 30 questões e a busca das respostas baseou-se em pesquisa sistemática da literatura para a identificação dos temas e respectivos graus de evidência. Foram selecionadas 11.069 publicações sobre doença do refluxo gastroesofágico, das quais 6.474 sobre diagnóstico e 4.595 sobre terapêutica. Em relação ao diagnóstico, 51 trabalhos alcançaram as exigências de Medicina baseada em evidências: 19 foram classificadas como grau A e 32 como grau B. Em relação à terapêutica, 158 alcançaram as exigências de Medicina baseada em evidências: 89 foram classificadas como grau A e 69 como grau B. No item Diagnóstico as respostas sustentadas por publicação de graus A e B foram aceitas. No item Tratamento, somente publicações grau A foram aceitas: as respostas apoiadas por publicações grau B foram submetidas a votação pelo Grupo de Consenso. A presente publicação apresenta as respostas às questões propostas com os trabalhos mais representativos seguidos por comentários pertinentes. Exemplos: 1) em pacientes com manifestações atípicas a pHmetria convencional pouco contribui para o diagnóstico de doença do refluxo gastroesofágico. A sensibilidade, entretanto, aumenta com o emprego de pHmetria de duplo canal. 2) Em pacientes com manifestações atípicas a impedância-pHmetria contribui substancialmente para o diagnóstico de doença do refluxo gastroesofágico. O exame, entretanto, é oneroso e pouco disponível em nosso país. 3) A avaliação dos sinais histológicos de esofagite eleva a probabilidade diagnóstica da doença do refluxo gastroesofágico, considerando-se que a observação das dimensões do espaço intercelular da mucosa esofágica aumenta a probabilidade de certeza diagnóstica e também permite a análise da resposta terapêutica. 4) Não há diferença na resposta clínica ao tratamento com inibidor da bomba protônica administrado em duas doses diárias quando comparado a uma única dose diária. 5) A longo prazo (>1 ano) a erradicação do $H$.pylori em pacientes com doença do refluxo gastroesofágico não reduz a presença de sintomas ou a elevada recurrência da enfermidade, embora reduza os sinais histológicos de inflamação. É muito provável que não ocorra associação entre a erradicação do H. pylori e as manifestações da doença do refluxo gastroesofágico. 6) A presença de hérnia hiatal exige doses maiores de IBP para o tratamento clínico. A ocorrência de migração permanente da junção esôfago-gástrica e as dimensões da hérnia $(>2 \mathrm{~cm})$ são fatores de pior prognóstico na doença do refluxo gastroesofágico. Nesses casos, as hérnias hiatais associadas à doença do refluxo gastroesofágico, especialmente as fixas e maiores do que $2 \mathrm{~cm}$ devem ser consideradas para tratamento cirúrgico. Os resultados da fundoplicatura laparoscópica tem se mostrado adequados.

DESCRITORES - Refluxo gastroesofágico. Esofagite péptica. Guias como assunto.

\section{REFERENCES}

1. Achem SR, Kolts BE, MacMath T, Richter J, Mohr D, Burton L, Castell DO. Effects of omeprazole versus placebo in treatment of noncardiac chest pain and gastroesophageal reflux. Dig Dis Sci. 1997;42:2138-45.

2. Ahlawat SK, Moh-Ud-Din R, Williams DC, Maher KA, Benjamin SB. A prospective study of gastric acid analysis and esophageal acid exposure in patients with gastroesophageal reflux refractory to medical therapy. Dig Dis Sci. 2005;50:2019-24.
3. Anvari M, Allen C. Surgical outcome in gastro-esophageal reflux disease patients with inadequate response to proton pump inhibitors. Surg Endosc. 2003;17:1029-35.

4. Anvari M, Allen C, Marshall J, Armstrong D, Goeree R, Ungar W, Goldsmith C. A randomized controlled trial of laparoscopic Nissen fundoplication versus proton pump inhibitors for treatment of patients with chronic gastroesophageal reflux disease: one-year follow-up. Surg Innov. 2006;13:238-49.

5. Bajbouj M, Becker V, Neuber M, Schmid RM, Meining A. Combined pH-metry/ impedance monitoring increases the diagnostic yield in patients with atypical gastroesophageal reflux symptoms. Digestion. 2007;76:223-8. 
6. Baldi F, Cappiello R, Cavoli C, Ghersi S, Torresan F, Roda E. Proton pump inhibitor treatment of patients with gastroesophageal reflux-related chronic cough: a comparison between two different daily doses of lansoprazole. World J Gastroenterol. 2006;12:82-8.

7. Bensenor IM, Hatanaka VMA. Diagnóstico clínico. In: Dantos IS, Silva LBB Lotufo PA, Bensenor IM, editores. Clínica médica - diagnóstico e tratamento. São Paulo: Sarvier; 2008. p.10-24.

8. Berg S, Hoffstein V, Gislason T. Acidification of distal esophagus and sleep-related breathing disturbances. Chest. 2004;125:2101-6.

9. Booth MI, Stratford J, Jones L, Dehn TC. Randomized clinical trial of laparoscopic total (Nissen) versus posterior partial (Toupet) fundoplication for gastro-oesophageal reflux disease based on preoperative oesophageal manometry. Br J Surg. 2008;95:57-63.

10. Calabrese C, Bortolotti M, Fabbri A, Areni A, Cenacchi G, Scialpi C, Miglioli M, Di Febo G. Reversibility of GERD ultrastructural alterations and relief of symptoms after omeprazole treatment. Am J Gastroenterol. 2005;100:537-42.

11. Calabrese C, Trerè D, Fabbri A, Cenacchi G, Vici M, Derenzini M, Di Febo G. Endoscopic appearance of GERD: putative role of cell proliferation. Dig Liver Dis. 2007;39:713-9.

12. Caletti GC, Ferrari A, Mattioli S, Zannoli R, Di Simone MP, Bocus P, Gozzett G, Barbara L. Endoscopy versus endoscopic ultrasonography in staging reflux esophagitis. Endoscopy. 1994;26:794-7.

13. Cameron AJ. Barrett's esophagus: prevalence and size of hiatal hernia. Am J Gastroenterol. 1999;94:2054-9.

14. Carling L, Axelsson CK, Forssell H, Stubberöd A, Kraglund K, Bonnevie O, Ekström P. Lansoprazole and omeprazole in the prevention of relapse of reflux oesophagitis: a long-term comparative study. Aliment Pharmacol Ther. 1998; 12:985-90.

15. Castell DO, Kahrilas PJ, Richter JE, Vakil NB, Johnson DA, Zuckerman S, Skammer W, Levine JG. Esomeprazole ( $40 \mathrm{mg}$ ) compared with lansoprazole (30 $\mathrm{mg}$ ) in the treatment of erosive esophagitis. Am J Gastroenterol. 2002;97:575-83.

16. Cats A, Schenk BE, Bloemena E, Roosedaal R, Lindeman J, Biemond I, KlinkenbergKnol EC, Meuwissen SG, Kuipers EJ. Parietal cell protrusions and fundic gland cysts during omeprazole maintenance treatment. Hum Pathol. 2000;31:684-90.

17. Caviglia R, Ribolsi M, Gentile M, Rabitti C, Emerenziani S, Guarino MP, Petitt T, Cicala M. Dilated intercellular spaces and acid reflux at the distal and proximal oesophagus in patients with non-erosive gastro-oesophageal reflux disease. Aliment Pharmacol Ther. 2007;25:629-36.

18. Chiocca JC, Olmos JA, Salis GB, Soifer LO, Higa R, Marcolongo M. Prevalence, clinical spectrum and atypical symptoms of gastro-oesophageal reflux in Argentina: a nationwide population-based study. Aliment Pharmacol Ther 2005;22:331-42.

19. Cookson R, Flood C, Koo B, Mahon D, Rhodes M. Short-term cost effectiveness and long-term cost analysis comparing laparoscopic Nissen fundoplication with proton-pump inhibitor maintenance for gastro-oesophageal reflux disease. $\mathrm{Br} \mathrm{J}$ Surg. 2005;92:700-6.

20. Dekkers CP, Beker JA, Thjodleifsson B, Gabryelewicz A, Bell NE, Humphries TJ. Double-blind comparison [correction of Double-blind, placebo-controlled comparison] of rabeprazole $20 \mathrm{mg}$ vs. omeprazole $20 \mathrm{mg}$ in the treatment of erosive or ulcerative gastro-oesophageal reflux disease. The European Rabeprazole Study Group. Aliment Pharmacol Ther. 1999;13:49-57.

21. Delchier JC, Cohen G, Humphries TJ. Rabeprazole $20 \mathrm{mg}$ once daily or $10 \mathrm{mg}$ twice daily is equivalent to omeprazole, $20 \mathrm{mg}$ once daily, in the healing of erosive gastroesophageal reflux disease. Scand J Gastroenterol. 2000;35:1245-50.

22. des Varannes SB, Sacher-Huvelin S, Vavasseur F, Masliah C, Le Rhun M, Aygalen P, Bonnot-Marlier S, Lequeux Y, Galmiche JP. Rabeprazole test for the diagnosis of gastro-oesophageal reflux disease: results of a study in a primary care setting. World J Gastroenterol. 2006;12:2569-73.

23. Devault KR, Johanson JF, Johnson DA, Liu S, Sostek MB. Maintenance of healed erosive esophagitis: a randomized six-month comparison of esomeprazole twenty milligrams with lansoprazole fifteen milligrams. Clin Gastroenterol Hepatol. 2006;4:852-9

24. Dickman R, Green C, Fass SS, Quan SF, Dekel R, Risner-Adler S, Fass R. Relationships between sleep quality and $\mathrm{pH}$ monitoring findings in persons with gastroesophageal reflux disease. J Clin Sleep Med. 2007;3:505-13.

25. dos Santos LH, Ribeiro IO, Sánchez PG, Hetzel JL, Felicetti JC, Cardoso PF Evaluation of pantoprazol treatment response of patients with asthma and gastroesophageal reflux: a randomized prospective double-blind placebo-controlled study. J Bras Pneumol. 2007;33:119-27.

26. El-Serag HB, Lee P, Buchner A, Inadomi JM, Gavin M, McCarthy DM. Lansoprazole treatment of patients with chronic idiopathic laryngitis: a placebocontrolled trial. Am J Gastroenterol. 2001;96:979-83.

27. El-Serag HB, Satia JA, Rabeneck L. Dietary intake and the risk of gastrooesophageal reflux disease: a cross sectional study in volunteers. Gut. 2005;54:11-7.
28. Endzinas Z, Jonciauskiene J, Mickevicius A, Kiudelis M. Hiatal hernia recurrence after laparoscopic fundoplication. Medicina (Kaunas). 2007;43:27-31.

29. An evidence-based appraisal of reflux disease management - The Genval Workshop Report. Gut 1999;44(suppl 2):s1-s16.

30. Fackler WK, Ours TM, Vaezi MF, Richter JE. Long-term effect of H2RA therapy on nocturnal gastric acid breakthrough. Gastroenterology. 2002;122:625-32.

31. Fennerty MB, Johanson JF, Hwang C, Sostek M. Efficacy of esomeprazole 40 $\mathrm{mg}$ vs. lansoprazole $30 \mathrm{mg}$ for healing moderate to severe erosive oesophagitis. Aliment Pharmacol Ther. 2005;21:455-63.

32. Fock KM, Teo EK, Ang TL, Chua TS, Ng TM, Tan YL. Rabeprazole vs esomeprazole in non-erosive gastro-esophageal reflux disease: a randomized, double-blind study in urban Asia. World J Gastroenterol. 2005;11:3091-8.

33. Franchi A, Brogelli B, Massi D, Santucci M, De Campora E, Gallo O. Dilation of intercellular spaces is associated with laryngo-pharyngeal reflux: an ultrastructura morphometric analysis of laryngeal epithelium. Eur Arch Otorhinolaryngol 2007;264:907-11.

34. Fraser AG, Morton RP, Gillibrand J. Presumed laryngo-pharyngeal reflux: investigate or treat? J Laryngol Otol. 2000;114:441-7.

35. French-Belgian Consensus Conference on Adult Gastro-oesophageal Reflux Disease 'Diagnosis and Treatment': report of a meeting held in Paris, France, on 21-22 January 1999. The Jury of the consensus conference. Eur J Gastroenterol. 2000;12:129-37.

36. Fujiwara Y, Machida A, Watanabe Y, Shiba M, Tominaga K, Watanabe T, Oshitani N, Higuchi K, Arakawa T. Association between dinner-to-bed time and gastroesophageal reflux disease. Am J Gastroenterol. 2005;100:2633-6.

37. Fuller CB, Hagen JA, DeMeester TR, Peters JH, Ritter M, Bremmer CG. The role of fundoplication in the treatment of type II paraesophageal hernia. Thorac Cardiovasc Surg. 1996;111:655-61.

38. Gatopoulou A, Mimidis K, Giatromanolaki A, Papadopoulos V, Polychronidis A, Lyratzopoulos N, Sivridis E, Minopoulos G. Impact of hiatal hernia on histological pattern of non-erosive reflux disease. BMC Gastroenterol. 2005;9:2.

39. Giannini EG, Zentilin P, Dulbecco P, Vigneri S, Scarlata P, Savarino V. Managemen strategy for patients with gastroesophageal reflux disease: a comparison between empirical treatment with esomeprazole and endoscopy-oriented treatment. Am J Gastroenterol. 2008;103:267-75.

40. Gillessen A, Beil W, Modlin IM, Gatz G, Hole U. $40 \mathrm{mg}$ pantoprazole and 40 $\mathrm{mg}$ esomeprazole are equivalent in the healing of esophageal lesions and relief from gastroesophageal reflux disease-related symptoms. J Clin Gastroenterol. 2004;38:332-40.

41. Gillies RS, Stratford JM, Booth MI, Dehn TC. Oesophageal pH monitoring using the Bravo catheter-free radio capsule. Eur J Gastroenterol Hepatol. 2007;19:57-63.

42. Gillies RS, Stratford JM, Booth MI, Dehn TC. Does laparoscopic antireflux surgery improve quality of life in patients whose gastro-oesophageal reflux disease is wel controlled with medical therapy? Eur J Gastroenterol Hepatol. 2008;20:430-5.

43. Glatzel D, Abdel-Qader M, Gatz G, Pfaffenberger B. Pantoprazole $40 \mathrm{mg}$ is as effective as esomeprazole $40 \mathrm{mg}$ to relieve symptoms of gastroesophageal reflux disease after 4 weeks of treatment and superior regarding the prevention of symptomatic relapse. Digestion. 2007;75(suppl 1):69-78

44. Goh KL, Benamouzig R, Sander P, Schwan T; EMANCIPATE. Efficacy of pantoprazole $20 \mathrm{mg}$ daily compared with esomeprazole $20 \mathrm{mg}$ daily in the maintenance of healed gastroesophageal reflux disease: a randomized, doubleblind comparative trial - the EMANCIPATE study. Eur J Gastroenterol Hepatol. 2007; 19:205-11.

45. Guda N, Partington S, Shaw MJ, Leo G, Vakil N. Unrecognized GERD symptoms are associated with excessive daytime sleepiness in patients undergoing sleep studies. Dig Dis Sci. 2007;52:2873-6.

46. Hagedorn C, Lönroth H, Rydberg L, Ruth M, Lundell L. Long-term efficacy of total (Nissen-Rossetti) and posterior partial (Toupet) fundoplication: results of a randomized clinical trial. J Gastrointest Surg. 2002;6:540-5.

47. Hamilton JW, Boisen RJ, Yamamoto DT, Wagner JL, Reichelderfer M. Sleeping on a wedge diminishes exposure of the esophagus to refluxed acid. Dig Dis Sci. 1988;33:518-22.

48. Harding SM, Richter JE, Guzzo MR, Schan CA, Alexander RW, Bradley LA. Asthma and gastroesophageal reflux: acid suppressive therapy improves asthma outcome. Am J Med. 1996;100:395-405.

49. Hila A, Agrawal A, Castell DO. Combined multichannel intraluminal impedance and $\mathrm{pH}$ esophageal testing compared to $\mathrm{pH}$ alone for diagnosing both acid and weakly acidic gastroesophageal reflux. Clin Gastroenterol Hepatol. 2007;5:172-7.

50. Ing AJ, Ngu MC, Breslin AB. Obstructive sleep apnea and gastroesophageal reflux. Am J Med. 2000;108(suppl 4A):120s-5s.

51. Johnson DA, Orr WC, Crawley JA, Traxler B, McCullough J, Brown KA, Roth T. Effect of esomeprazole on nighttime heartburn and sleep quality in patients with GERD: a randomized, placebo-controlled trial. Am J Gastroenterol. 2005;100:1914-22. 
52. Johnsson F, Moum B, Vilien M, Grove O, Simren M, Thoring M. On-demand treatment in patients with oesophagitis and reflux symptoms: comparison of lansoprazole and omeprazole. Scand J Gastroenterol. 2002;37:642-7.

53. Johnsson F, Hatlebakk JG, Klintenberg AC, Román J. Symptom relieving effect of esomeprazole $40 \mathrm{mg}$ daily in patients with heartburn. Scand J Gastroenterol. 2003;38:347-53.

54. Johnsson F, Hatlebakk JG, Klintenberg AC, Román J, Toth E, Stubberöd A, Falk A, Edin R. One-week omeprazole treatment: an effective confirmatory test in patients with suspected gastroesophageal reflux disease. Scand J Gastroenterol. 2003;38:354-9.

55. Jones MP, Sloan SS, Rabine JC, Ebert CC, Huang CF, Kahrilas PJ. Hiatal hernia size is the dominant determinant of esophagitis presence and severity in gastroesophageal reflux disease. Am J Gastroenterol. 2001;96:1711-7.

56. Jones RB, Lydeard SE, Hobbs FD, Kenkre JE, Williams EL, Jones SJ, Repper JA, Caldow JL, Dunwoodie WM, Bottomley JM. Dyspepsia in England and Scotland. Gut. 1990;31:401-5.

57. Kadakia SC, Kikendall JW, Maydonovitch C, Johnson LF. Effect of cigarette smoking on gastroesophageal reflux measured by 24-h ambulatory esophageal pH monitoring. Am J Gastroenterol. 1995;90:1785-90.

58. Kahrilas PJ, Falk GW, Johnson DA, Schmitt C, Collins DW, Whipple J, D’Amico D, Hamelin B, Joelsson B. Esomeprazole improves healing and symptom resolution as compared with omeprazole in reflux oesophagitis patients: a randomized controlled trial. The Esomeprazole Study Investigators. Aliment Pharmacol Ther. 2000;14:1249-58.

59. Kahrilas PJ, Miner P, Johanson J, Mao L, Jokubaitis L, Sloan S. Efficacy of rabeprazole in the treatment of symptomatic gastroesophageal reflux disease. Dig Dis Sci. 2005;50:2009-18.

60. Kamolz T, Granderath FA, Schweiger UM, Pointner R. Laparoscopic Nissen fundoplication in patients with nonerosive reflux disease. Long-term quality-oflife assessment and surgical outcome. Surg Endosc. 2005;19:494-500.

61. Kawamura O, Sekiguchi T, Kusano M, Horikoshi T, Kikuchi K, Miyazaki M, Yamada T, Ohwada T. Endoscopic ultrasonographic abnormalities and lower esophageal sphincter function in reflux esophagitis. Dig Dis Sci. 1995;40:598-605.

62. Khoury RM, Katz PO, Hammod R, Castell DO. Bedtime ranitidine does not eliminate the need for a second daily dose of omeprazole to suppress nocturnal gastric pH. Aliment Pharmacol Ther. 1999;13:675-8.

63. Kim JH, Rhee PL, Park EH, Son HJ, Kim JJ, Rhee JC. Clinical usefulness of subgrouping of patients with non-cardiac chest pain according to characteristic symptoms in Korea. J Gastroenterol Hepatol. 2007;22:320-5.

64. Kim N, Lee SW, Cho SI, Park CG, Yang CH, Kim HS, Rew JS, Moon JS, Kim S, Park SH, Jung HC, Chung IS; H. pylori and Gerd Study Group of Korean College of Helicobacter and Upper Gastrointestinal Research. The prevalence of and risk factors for erosive oesophagitis and non-erosive reflux disease: a nationwide multicentre prospective study in Korea. Aliment Pharmacol Ther. 2008;27:173-85.

65. Kjellin A, Ramel S, Rossner S, Thor K. Gastroesophageal reflux in obese patients is not reduced by weight reduction. Scand J Gastroenterol. 1996;31:1047-51.

66. Klaus A, Gadenstaetter M, Mühlmann G, Kirchmayr W, Profanter C, Achem SR, Wetscher GJ. Selection of patients with gastroesophageal reflux disease for antireflux surgery based on esophageal manometry. Dig Dis Sci. 2003;48:1719-22.

67. Körner T, Schütze K, van Leendert RJ, Fumagalli I, Costa Neves B, Bohuschke M, Gatz G. Comparable efficacy of pantoprazole and omeprazole in patients with moderate to severe reflux esophagitis. Results of a multinational study. Digestion. 2003;67:6-13.

68. Kuipers EJ, Nelis GF, Klinkenberg-Knol EC, Snel P, Goldfain D, Kolkman JJ, Festen HP, Dent J, Zeitoun P, Havu N, Lamm M, Walan A. Cure of Helicobacter pylori infection in patients with reflux oesophagitis treated with long term omeprazole reverses gastritis without exacerbation of reflux disease: results of a randomised controlled trial. Gut. 2004;53:12-20.

69. Labenz J, Armstrong D, Lauritsen K, Katelaris P, Schmidt S, Schütze K, Wallner G, Juergens H, Preiksaitis H, Keeling N, Nauclér E, Eklund S; Expo Study Investigators. A randomized comparative study of esomeprazole $40 \mathrm{mg}$ versus pantoprazole $40 \mathrm{mg}$ for healing erosive oesophagitis: the EXPO study. Aliment Pharmacol Ther. 2005;21:739-46.

70. Lauritsen K, Devière J, Bigard MA, Bayerdörffer E, Mózsik G, Murray F, Kristjánsdóttir S, Savarino V, Vetvik K, De Freitas D, Orive V, Rodrigo L, Fried M, Morris J, Schneider H, Eklund S, Larkö A; Metropole study results. Esomeprazole $20 \mathrm{mg}$ and lansoprazole $15 \mathrm{mg}$ in maintaining healed reflux oesophagitis: Metropole study results. Aliment Pharmacol Ther. 2003;17:333-41.

71. Lightdale CJ, Schmitt C, Hwang C, Hamelin B. A multicenter, randomized, double-blind, 8-week comparative trial of low-dose esomeprazole $(20 \mathrm{mg})$ and standard-dose omeprazole $(20 \mathrm{mg})$ in patients with erosive esophagitis. Dig Dis Sci. 2006;51:852-7.
72. Littner MR, Leung FW, Ballard ED 2nd, Huang B, Samra NK; Lansoprazole Asthma Study Group. Effects of 24 weeks of lansoprazole therapy on asthma symptoms, exacerbations, quality of life, and pulmonary function in adult asthmatic patients with acid reflux symptoms. Chest. 2005;128:1128-35.

73. Livingston CD, Jones HL Jr, Askew RE Jr, Victor BE, Askew RE Sr. Laparoscopic hiatal hernia repair in patients with poor esophageal motility or paraesophagea herniation. Am Surg. 2001;67:987-91.

74. Locke GR 3rd, Talley NJ, Fett SL, Zinsmeister AR, Melton LJ 3rd. Prevalence and clinical spectrum of gastroesophageal reflux: a population-based study in Olmsted County, Minnesota. Gastroenterology. 1997;112:1448-56.

75. Lundell L, Ruth M, Sandberg N, Bove-Nielsen M. Does massive obesity promote abnormal gastroesophageal reflux? Dig Dis Sci. 1995;40:1632-5.

76. Lundell L, Miettinen P, Myrvold HE, Pedersen SA, Thor K, Lamm M, Blomqvist A, Hatlebakk JG, Janatuinen E, Levander K, Nyström P, Wiklund I. Long-term management of gastro-oesophageal reflux disease with omeprazole or open antireflux surgery: results of a prospective, randomized clinical trial. The Nordic GORD Study Group. Eur J Gastroenterol Hepatol. 2000;12:879-87.

77. Lundell L, Havu N, Miettinen P, Myrvold HE, Wallin L, Julkunen R, Levander K, Hatlebakk JG, Liedman B, Lamm M, Malm A, Walan A; Nordic Gerd Study Group. Changes of gastric mucosal architecture during long-term omeprazole therapy: results of a randomized clinical trial. Aliment Pharmacol Ther. 2006;23:639-47.

78. Lundell L, Attwood S, Ell C, Fiocca R, Galmiche JP, Hatlebakk J, Lind T, Junghard O; LOTUS trial collaborators. Comparing laparoscopic antireflux surgery with esomeprazole in the management of patients with chronic gastro-oesophageal reflux disease: a 3-year interim analysis of the LOTUS trial. Gut. 2008;57:1207-13.

79. Madan K, Ahuja V, Kashyap PC, Sharma MP. Comparison of efficacy of pantoprazole alone versus pantoprazole plus mosapride in therapy of gastroesophageal reflux disease: a randomized trial. Dis Esophagus. 2004; 17:274-8.

80. Mahon D, Rhodes M, Decadt B, Hindmarsh A, Lowndes R, Beckingham I, Koo B, Newcombe RG. Randomized clinical trial of laparoscopic Nissen fundoplication compared with proton-pump inhibitors for treatment of chronic gastro-oesophageal reflux. Br J Surg. 2005;92:695-9.

81. Mainie I, Tutuian R, Agrawal A, Adams D, Castell DO. Combined multichannel intraluminal impedance-pH monitoring to select patients with persistent gastrooesophageal reflux for laparoscopic Nissen fundoplication. Br J Surg. 2006;93:1483-7.

82. Mainie I, Tutuian R, Shay S, Vela M, Zhang X, Sifrim D, Castell DO. Acid and non-acid reflux in patients with persistent symptoms despite acid suppressive therapy: a multicentre study using combined ambulatory impedance-pH monitoring. Gut. 2006;55:1398-402.

83. Mark LA, Okrainec A, Ferri LE, Feldman LS, Mayrand S, Fried GM. Comparison of patient-centered outcomes after laparoscopic Nissen fundoplication for gastroesophageal reflux disease or paraesophageal hernia. Surg Endosc. 2008;22:343-7.

84. Mathus-Vliegen EM, Tygat GN. Gastrooesophageal reflux in obese subjects: influence of overweight, weight loss and chronic gastric balloon distension. Scand J Gastroenterol. 2002;37:1246-52.

85. Mattioli S, D’Ovidio F, Di Simone MP, Bassi F, Brusori S, Pilotti V, Felice V, Ferruzzi L, Guernelli N. Clinical and surgical relevance of the progressive phases of intrathoracic migration of the gastroesophageal junction in gastroesophageal reflux disease. J Thorac Cardiovasc Surg. 1998;116:267-75.

86. Maziak DE, Todd TR, Pearson FG. Massive hiatus hernia: evaluation and surgical management. J Thorac Cardiovasc Surg. 1998;115:53-60.

87. Mehta S, Bennett J, Mahon D, Rhodes M. Prospective trial of laparoscopic Nissen fundoplication versus proton pump inhibitor therapy for gastroesophageal reflux disease: seven-year follow-up. J Gastrointest Surg. 2006;10:1312-6.

88. Meineche-Schmidt V, Juhl HH, Østergaard JE, Luckow A, Hvenegaard A. Costs and efficacy of three different esomeprazole treatment strategies for long-term management of gastro-oesophageal reflux symptoms in primary care. Aliment Pharmacol Ther. 2004;19:907-15.

89. Moayyedi P, Wason C, Peacock R, Walan A, Bardhan K, Axon AT, Dixon MF Changing patterns of Helicobacter pylori gastritis in long-standing acid suppression. Helicobacter. 2000;5:206-14.

90. Moayyedi P, Bardhan C, Young L, Dixon MF, Brown L, Axon AT. Helicobacter pylori eradication does not exacerbate reflux symptoms in gastroesophageal reflux disease. Gastroenterology. 2001;121:1120-6.

91. Mönnikes H, Pfaffenberger B, Gatz G, Hein J, Bardhan KD. Novel measurement of rapid treatment success with ReQuest: first and sustained symptom relief as outcome parameters in patients with endoscopy-negative GERD receiving $20 \mathrm{mg}$ pantoprazole or $20 \mathrm{mg}$ esomeprazole. Digestion. 2007;75(suppl 1):62-8.

92. Moraes-Filho JPP, Cecconello I, Gama-Rodrigues J, Castro LP, Henry MA, Meneghelli UG, Quigley E. Brazilian consensus on gastroesophageal reflux disease: proposals for assessment, classification, and management. Am J Gastroenterol. 2002;97:241-8 
93. Moraes-Filho JPP, Chinzon D, Eisig JN, Hashimoto CL, Zaterka S. Prevalence of heartburn and gastroesophageal reflux disease in the urban Brazilian population. Arq Gastroenterol. 2005;42:122-7.

94. Morgenthal CB, Lin E, Shane MD, Hunter JG, Smith CD. Who will fail laparoscopic Nissen fundoplication? Preoperative prediction of long-term outcomes. Surg Endosc. 2007;21:1978-84.

95. Mulder CJ, Westerveld BD, Smit JM, Oudkerk Pool M, Otten MH, Tan TG, van Milligen de Wit AW, de Groot GH; Dutch Omeprazole MUPS Study Group. A double-blind, randomized comparison of omeprazole Multiple Unit Pellet System (MUPS) $20 \mathrm{mg}$, lansoprazole $30 \mathrm{mg}$ and pantoprazole $40 \mathrm{mg}$ in symptomatic reflux oesophagitis followed by 3 months of omeprazole MUPS maintenance treatment: a Dutch multicentre trial. Eur J Gastroenterol Hepatol. 2002;14:649-56.

96. Myrvold HE, Lundell L, Miettinen P, Pedersen SA, Liedman B, Hatlebakk J, Julkunen R, Levander K, Lamm M, Mattson C, Carlsson J, Ståhlhammar NO; Nordic GORD Study Group. The cost of long term therapy for gastro-oesophagea reflux disease: a randomized trial comparing omeprazole and open antireflux surgery. Gut. 2001;49:488-94.

97. Nandurkar S, Locke GR 3rd, Fett S, Zinsmeister AR, Cameron AJ, Talley NJ. Relationship between body mass index, diet, exercise and gastro-oesophageal reflux symptoms in a community. Aliment Pharmacol Ther. 2004;20:497-505.

98. Nocon M, Labenz J, Willich SN. Lifestyle factors and symptoms of gastrooesophageal reflux -- a population-based study. Aliment Pharmacol Ther. 2006;23:169-74.

99. Noordzij JP, Khidr A, Desper E, Meek RB, Reibel JF, Levine PA. Correlation of $\mathrm{pH}$ probe-measured laryngopharyngeal reflux with symptoms and signs of reflux laryngitis. Laryngoscope. 2002;112:2192-5.

100. Patterson RN, Johnston BT, MacMahon J, Heaney LG, McGarvey LP. Oesophageal $\mathrm{pH}$ monitoring is of limited value in the diagnosis of, "reflux-cough. Eur Respir J. 2004;24:724-7.

101. Pehl C, Wendl B, Pfeiffer A. White wine and beer induce gastro-oesophageal reflux in patients with reflux disease. Aliment Pharmacol Ther. 2006;23:1581-6.

102. Penagini R, Mangano M, Bianchi PA. Effect of increasing the fat content but not the energy load of a meal on gastro-oesophageal reflux and lower oesophageal sphincter motor function. Gut. 1998;42:330-3

103. Phillips B, Ball C, Sackett D, Badenoch D, Straus S, Haynes RB, Dawes M. Oxford Centre for evidence-based Medicine. Levels of evidence; May 2001.

104. Piesman M, Hwang I, Maydonovitch C, Wong RK. Nocturnal reflux episodes following the administration of a standardized meal. Does timing matter? Am J Gastroenterol. 2007;102:2128-34

105. Piloto RR, Fama F, Giacobbe G, Gioffre Florio MA, Cogliandolo A. Quality of life and predictors of long-term outcome in patients undergoing open Nissen fundoplication for chronic gastroesophageal reflux. Am J Surg. 2006;191:470-8.

106. Rackoff A, Agrawal A, Hila A, Mainie I, Tutuian R, Castell DO. Histamine-2 receptor antagonists at night improve gastroesophageal reflux disease symptoms for patients on proton pump inhibitor therapy. Dis Esophagus. 2005;18:370-3.

107. Raghu G, Freudenberger TD, Yang S, Curtis JR, Spada C, Hayes J, Sillery JK, Pope CE 2nd, Pellegrini CA. High prevalence of abnormal acid gastro-oesophageal reflux in idiopathic pulmonary fibrosis. Eur Respir J. 2006;27:136-42.

108. Richter JE, Kovacs TO, Greski-Rose PA, Huang section sign B, Fisher R. Lansoprazole in the treatment of heartburn in patients without erosive oesophagitis. Aliment Pharmacol Ther. 1999;13:795-804.

109. Richter JE, Bochenek W. Oral pantoprazole for erosive esophagitis: a placebocontrolled, randomized clinical trial. Pantoprazole US GERD Study Group. Am J Gastroenterol. 2000;95:3071-80.

110. Richter JE, Kahrilas PJ, Sontag SJ, Kovacs TO, Huang B, Pencyla JL. Comparing lansoprazole and omeprazole in onset of heartburn relief: results of a randomized, controlled trial in erosive esophagitis patients. Am J Gastroenterol. 2001;96: 3089-98.

111. Rindi G, Fiocca R, Morocutti A, Jacobs A, Miller N, Thjodleifsson B; European Rabeprazole Study Group. Effects of 5 years of treatment with rabeprazole or omeprazole on the gastric mucosa. Eur J Gastroenterol Hepatol. 2005; 17:559-66.

112. Robinson M, Rodriguez-Stanley S, Ciociola AA, Filinto J, Zubaidi S, Miner PB Jr, Gardner JD. Control of nocturnal gastric acidity: a role for low dose bedtime ranitidine to supplement daily omeprazole. Dig Dis Sci. 2002;47:265-73.

113. Roman S, Poncet G, Serraj I, Zerbib F, Boulez J, Mion F. Characterization of reflux events after fundoplication using combined impedance- $\mathrm{pH}$ recording. $\mathrm{Br}$ J Surg. 2007;94:48-52.

114. Rosaida MS, Goh KL. Gastro-oesophageal reflux disease, reflux oesophagitis and nonerosive reflux disease in a multiracial Asian population: a prospective, endoscopy based study. Eur J Gastroenterol Hepatol. 2004;16:495-501.

115. Rossi M, Barreca M, de Bortoli N, Renzi C, Santi S, Gennai A, Bellini M, Costa F, Conio M, Marchi S. Efficacy of Nissen fundoplication versus medical therapy in the regression of low-grade dysplasia in patients with Barrett esophagus: a prospective study. Ann Surg. 2006;243:58-63.
116. Santos LH, Ribeiro IO, Sánchez PG, Hetzel JL, Felicetti JC, Cardoso PF. Evaluation of pantoprazol treatment response of patients with asthma and gastroesophageal reflux: a randomized prospective double-blind placebo-controlled study. J Bras Pneumol. 2007:33:119-27.

117. Schenk BE, Kuipers EJ, Klinkenberg-Knol EC, Festen HP, Jansen EH, Tuynman HA, Schrijver M, Dieleman LA, Meuwissen SG. Omeprazole as a diagnostic tool in gastroesophageal reflux disease. Am J Gastroenterol. 1997;92:1997-2000.

118. Schindlbeck NE, Heinrich C, Dendorfer A, Pace F, Muller-Lissner SA. Influence of smoking and esophageal intubation on esophageal $\mathrm{pH}$-metry. Gastroenterology. 1987;92:1994-7.

119. Schmitt C, Lightdale CJ, Hwang C, Hamelin B. A multicenter, randomized, double-blind, 8-week comparative trial of standard doses of esomeprazole (40 $\mathrm{mg}$ ) and omeprazole $(20 \mathrm{mg})$ for the treatment of erosive esophagitis. Dig Dis Sci. 2006;51:844-50.

120. Scholten T, Gatz G, Hole U. Once-daily pantoprazole $40 \mathrm{mg}$ and esomeprazole $40 \mathrm{mg}$ have equivalent overall efficacy in relieving GERD-related symptoms. Aliment Pharmacol Ther. 2003;18:587-94.

121. Sermon F, Vanden Brande S, Roosens B, Mana F, Deron P, Urbain D. Is ambulatory 24-h dual-probe $\mathrm{pH}$ monitoring useful in suspected ENT manifestations of GERD? Dig Liver Dis. 2004;36:105-10.

122. Sgouros SN, Mpakos D, Rodias M, Vassiliades K, Karakoidas C, Andrikopoulos E, Stefanidis G, Mantides A. et al. Prevalence and axial length of hiatus hernia in patients, with nonerosive reflux disease: a prospective study. J Clin Gastroenterol. 2007:41:814-8.

123. Sharma B, Sharma M, Daga MK, Sachdev GK, Bondi E. Effect of omeprazole and domperidone on adult asthmatics with gastroesophageal reflux. World $\mathrm{J}$ Gastroenterol. 2007;13:1706-10.

124. Sharma N, Agrawal A, Freeman J, Vela MF, Castell D. An analysis of persistent symptoms in acid-suppressed patients undergoing impedance-pH monitoring. Clin Gastroenterol Hepatol. 2008;6:521-4

125. Sifrim D, Dupont L, Blondeau K, Zhang X, Tack J, Janssens J. Weakly acidic reflux in patients with chronic unexplained cough during 24 hour pressure, $\mathrm{pH}$, and impedance monitoring. Gut. 2005;54:449-54.

126. Solcia E, Villani L, Luinetti O, Trespi E, Strada E, Tinelli C, Fiocca R. Altered intercellular glycoconjugates and dilated intercellular spaces of esophageal epithelium in reflux disease. Virchows Arch. 2000;436:207-16.

127. Stanciu C, Bennett JR. Effects of posture on gastro-oesophageal reflux. Digestion. 1977; $15: 104-9$

128. Stanghellini V. Relationship between upper gastrointestinal symptoms and lifestyle, psychosocial factors and comorbidity in the general population: results from the Domestic/International Gastroenterology Surveillance Study (DIGEST). Scand J Gastroenterol Suppl. 1999;231:29-37.

129. Stolte M, Vieth M, Schmitz JM, Alexandridis T, Seifert E. Effects of long-term treatment with proton pump inhibitors in gastro-oesophageal reflux disease on the histological findings in the lower oesophagus. Scand J Gastroenterol. 2000;35:1125-30.

130. Strate U, Emmermann A, Fibbe C, Layer P, Zornig C. Laparoscopic fundoplication: Nissen versus Toupet two-year outcome of a prospective randomized study of 200 patients regarding preoperative esophageal motility. Surg Endosc. 2008;22:21-30

131. Sweet MP, Patti MG, Leard LE, Golden JA, Hays SR, Hoopes C, Theodore PR Gastroesophageal reflux in patients with idiopathic pulmonary fibrosis referred for lung transplantation. J Thorac Cardiovasc Surg. 2007;133:1078-84.

132. Thjodleifsson B, Beker JA, Dekkers C, Bjaaland T, Finnegan V, Humphries TJ Rabeprazole versus omeprazole in preventing relapse of erosive or ulcerative gastroesophageal reflux disease: a double-blind, multicenter, European trial. The European Rabeprazole Study Group. Dig Dis Sci. 2000;45:845-53.

133. Tobin RW, Pope CE 2nd, Pellegrini CA, Emond MJ, Sillery J, Raghu G. Increased prevalence of gastroesophageal reflux in patients with idiopathic pulmonary fibrosis. Am J Respir Crit Care Med. 1998;158:1804-8.

134. Torres-Quevedo R, Manterola C, Sanhueza A, Bustos L, Pineda V, Vial M Diagnostic properties of a symptoms scale for diagnosing reflux esophagitis. J Clin Epidemiol. 2008; 62:97-101.

135. Tsai HH, Chapman R, Shepherd A, McKeith D, Anderson M, Vearer D, Duggan $\mathrm{S}$, Rosen JP; COMMAND Study Group. Esomeprazole $20 \mathrm{mg}$ on-demand is more acceptable to patients than continuous lansoprazole $15 \mathrm{mg}$ in the longterm maintenance of endoscopy-negative gastro-oesophageal reflux patients: the COMMAND Study. Aliment Pharmacol Ther. 2004;20:657-65.

136. Tutuian R, Vela MF, Hill EG, Mainie I, Agrawal A, Castell DO. Characteristics of symptomatic reflux episodes on acid suppressive therapy. Am J Gastroenterol. 2008;103:1090-6.

137. Vaezi MF, Richter JE, Stasney CR, Spiegel JR, Iannuzzi RA, Crawley JA, Hwang C, Sostek MB, Shaker R. Treatment of chronic posterior laryngitis with esomeprazole. Laryngoscope. 2006;116:254-60. 
138. Vakil N, van Zanten SV, Kahrilas P, Dent J, Jones R; Global Consensus Group. The Montreal definition and classification of gastroesophageal reflux disease: a global evidence-based consensus. Am J Gastroenterol. 2006;101:1900-20.

139. Vieth M, Kulig M, Leodolter A, Nauclér E, Jaspersen D, Labenz J, MeyerSabellek W, Lind T, Willich S, Malfertheiner P, Stolte M. Histological effects of esomeprazole therapy on the squamous epithelium of the distal oesophagus. Aliment Pharmacol Ther. 2006;23:313-9.

140. Vigneri S, Termini R, Leandro G, Badalamenti S, Pantalena M, Savarino V, Di Mario F, Battaglia G, Mela GS, Pilotto A, et al. A comparison of five maintenance therapies for reflux esophagitis. N Engl J Med. 1995;333:1106-10.

141. Wang JH, Luo JY, Dong L, Gong J, Tong M. Epidemiology of gastroesophagea reflux disease: a general population-based study in Xi'an of Northwest China. World J Gastroenterol. 2004;10:1647-51.

142. Waring JP, Eastwood TF, Austin JM, Sanowski RA. The immediate effects of cessation of cigarette smoking on gastroesophageal reflux. Am J Gastroenterol. 1989;84:1076-8.

143. Weigt J, Mönkemüller K, Peitz U, Malfertheiner P. Multichannel intraluminal impedance and $\mathrm{pH}$-metry for investigation of symptomatic gastroesophageal reflux disease. Dig Dis 2007;25:179-82.

144. Wenner J, Johnsson F, Johansson J, Oberg S. Wireless esophageal pH monitoring is better tolerated than the catheter-based technique: results from a randomized cross-over trial. Am J Gastroenterol. 2007;102:239-45.
145. Wetscher GJ, Glaser K, Gadenstaetter M, Profanter C, Hinder RA. The effect of medical therapy and antireflux surgery on dysphagia in patients with gastroesophageal reflux disease without esophageal stricture. Am J Surg. 1999;177: 189-92.

146. Wijnhoven BP, Lally CJ, Kelly JJ, Myers JC, Watson DI. Use of antireflux medication after antireflux surgery. J Gastrointest Surg. 2008;12:510-7.

147. Wo JM, Koopman J, Harrell SP, Parker K, Winstead W, Lentsch E. Double-blind, placebo-controlled trial with single-dose pantoprazole for laryngopharyngeal reflux. Am J Gastroenterol. 2006;101:1972-8.

148. Wu JC, Chan FK, Ching JY, Leung WK, Hui Y, Leong R, Chung SC, Sung JJ. Effect of Helicobacter pylori eradication on treatment of gastro-oesophageal reflux disease: a double blind, placebo controlled, randomised trial. Gut. 2004;53: 174-9

149. Zentilin P, Savarino V, Mastracci L, Spaggiari P, Dulbecco P, Ceppa P, Savarino E, Parodi A, Mansi C, Fiocca R. Reassessment of the diagnostic value of histology in patients with GERD, using multiple biopsy sites and an appropriate control group. Am J Gastroenterol. 2005;100:2299-306.

150. Zornig C, Strate U, Fibbe C, Emmermann A, Layer P. Nissen vs Toupet laparoscopic fundoplication. Surg Endosc. 2002;16:758-66.

Received 26/6/2009. Accepted 21/7/2009. 